\title{
Vectors of disease at the northern distribution limit of the genus Dermacentor in Eurasia: D. reticulatus and D. silvarum
}

\author{
Franz Rubel ${ }^{1}$ (D) . Katharina Brugger ${ }^{1}$. Oxana A. Belova ${ }^{2}$. Ivan S. Kholodilov ${ }^{2}$. \\ Yuliya M. Didyk ${ }^{3,4}$ - Lina Kurzrock ${ }^{5}$ - Ana L. García-Pérez ${ }^{6}$. Olaf Kahl ${ }^{7}$
}

Received: 8 June 2020 / Accepted: 7 August 2020 / Published online: 19 August 2020

(C) The Author(s) 2020

\begin{abstract}
The two ixodid tick species Dermacentor reticulatus (Fabricius) and Dermacentor silvarum Olenev occur at the northern distribution limit of the genus Dermacentor in Eurasia, within the belt of $34-60^{\circ} \mathrm{N}$ latitude. Whilst the distribution area of D. reticulatus extends from the Atlantic coast of Portugal to Western Siberia, that of D. silvarum extends from Western Siberia to the Pacific coast. In Western Siberia, the distribution areas of the two Dermacentor species overlap. Although the two tick species are important vectors of disease, detailed information concerning the entire distribution area, climate adaptation, and proven vector competence is still missing. A dataset was compiled, resulting in 2188 georeferenced $D$. reticulatus and $522 D$. silvarum locations. Up-to-date maps depicting the geographical distribution and climate adaptation of the two Dermacentor species are presented. To investigate the climate adaptation of the two tick species, the georeferenced locations were superimposed on a high-resolution map of the Köppen-Geiger climate classification. The frequency distribution of $D$. reticulatus under different climates shows two major peaks related to the following climates: warm temperate with precipitation all year round (57\%) and boreal with precipitation all year round (40\%). The frequency distribution of $D$. silvarum shows also two major peaks related to boreal climates with precipitation all year round (30\%) and boreal winter dry climates (60\%). Dermacentor silvarum seems to be rather flexible concerning summer temperatures, which can range from cool to hot. In climates with cool summers $D$. reticulatus does not occur, it prefers warm and to a lesser extent hot summers. Lists are given in this paper for cases of proven vector competence for various agents of both Dermacentor species. For the first time, the entire distribution areas of $D$. reticulatus and $D$. silvarum were mapped using georeferenced data. Their climate adaptations were quantified by Köppen profiles.
\end{abstract}

Keywords Tick-borne diseases - Geographical distribution · Climate adaptation · KöppenGeiger climate classification

Franz Rubel

franz.rubel@vetmeduni.ac.at

Extended author information available on the last page of the article 


\section{Introduction}

The two ixodid tick species, Dermacentor reticulatus (Fabricius) and Dermacentor silvarum Olenev are endemic at the northern distribution limit of the genus Dermacentor in Eurasia up to approximately $60^{\circ} \mathrm{N}$.

Dermacentor reticulatus (in former Russian literature often called D. pictus) is the second most often reported tick species after Ixodes ricinus in central Europe (Rubel et al. 2014). In sufficiently humid habitats $D$. reticulatus may occur sympatrically with $I$. ricinus or Ixodes persulcatus as well as Haemaphysalis concinna (Kahl et al. 1992; Hornok and Farkas 2009; Rybárová et al. 2017). The geographical distribution of D. reticulatus in Europe was recently mapped by Rubel et al. (2016), whereas a distribution map for the former Soviet Union was published by Kulik and Vinokurova (Kulik and Vinokurova 1983b). The documented distribution of D. reticulatus ranges from northern Portugal to Western Siberia. In Europe, distribution is limited to the south by the Mediterranean climatic zone, in which $D$. reticulatus does not occur (exceptions discussed below). In Asia, the cold steppes of Kazakhstan provide a natural barrier for that species. Preferred habitats are alluvial forests where it can survive flooding for certain periods (Nosek 1972). However, it readily colonizes also somewhat drier habitats such as fallow and heathland as well as grassland interspersed with bushes or trees. Remarkable is its occurrence in some urban and suburban areas of big cities such as Berlin (Dautel et al. 2006; Schreiber et al. 2014), Vienna (Leschnik et al. 2012), Budapest (Hornok et al. 2014), Kyiv (Didyk et al. 2017), Moscow (Yankovskaya et al. 2017), and Tomsk (Romanenko et al. 2017). Larvae and nymphs feed on certain rodent species, whereas adults parasitize larger mammals like cattle, deer and dogs but only occasionally bite humans. Whilst only $0.5 \%$ of ticks attaching to humans are D. reticulatus in Northern Spain (Merino et al. 2005), where D. reticulatus is rare, this proportion is above $15 \%$ in Western Siberia (Valitskaya et al. 2016). The life cycle lasts 1-2 years or even longer, and the development from egg to unfed adult has to take place in one growing season. Unfed adults are quite long-lived with a life span of up to 3-4 years (Balashov 1972). They are active from late August/September through April/May, interrupted by low temperatures or snow cover in the winter, and enter a behavioural diapause in summer (Belozerov 1982). Oviposition takes place exclusively in spring and the resultant short-lived larvae and nymphs have their main activity periods in July and August, respectively, irrespective of their geographic origin (Kahl and Dautel 2013). Amongst others, D. reticulatus is considered the main vector of the Omsk haemorrhagic fever virus in Western Siberia (Růžek et al. 2010) and of Babesia canis in Europe (Leschnik et al. 2012; Jongejan et al. 2015). It is also known to be infected with bacteria such as Rickettsia raoultii (Barandika et al. 2008).

Dermacentor silvarum (formerly sometimes referred to as D. asiaticus) is widely distributed in taiga forests in south-eastern Russia (Kulik and Vinokurova 1983a), northern Mongolia (Kiefer et al. 2010), and northeastern and central China (Yu et al. 2011). It can also be found in big cities like the Chinese capital Beijing (Li et al. 2002; Guo et al. 2009). The western distribution limit is in Western Siberia, where D. silvarum overlaps with $D$. reticulatus. In the east, D. silvarum was documented down to the coast of Sakhalin, the largest island of the Russian Federation in the North Pacific (Kiefer et al. 2010). Its highest abundance has been observed in forest clearings, dry bushland, pastures, and other light-flooded biotopes. In Mongolia, D. silvarum has been found in the taiga forests in the northern part of the country and in the forests surrounding the Khentii mountains (Cerný et al., 2019). Adult females feed mostly on ungulates and wild-boar, but also on hares and 
hedgehogs. Immatures feed on rodents, hares, and hedgehogs. In Irkutsk, Eastern Siberia, $15 \%$ of tick attacks on humans are caused by D. silvarum and D. nuttalli (Khasnatinov et al. 2016). The life cycle takes approximately one year. The minimum temperatures necessary for development are $8.6^{\circ} \mathrm{C}$ for the larvae and $9.7^{\circ} \mathrm{C}$ for the nymphs (Beljaeva 1975). Questing adults can be found from late February to early June. They may then enter a behavioural diapause in summer (Belozerov 1982). Adult females engorged after spring enter a reproductive diapause and oviposit in spring of the following year (Balashov 1972). Larvae are active from June to August and nymphs from August to early September (Yu et al. 2010). Amongst others, D. silvarum is considered a vector of the tick-borne encephalitis (TBE) virus (Kholodilov et al. 2019) and is also known to be infected with various pathogens.

Maps showing the complete detailed geographical distribution of D. reticulatus and $D$. silvarum are missing. In order to compile such maps, a list of georeferenced tick locations is required that was previously collected only for D. reticulatus in Europe (Estrada-Peña et al. 2013; Rubel et al. 2016) and D. silvarum in China (Zhang et al. 2019). Large areas of eastern Europe and Asia (Ukraine, Belarus, Kazakhstan, Mongolia, and Russia) have not or only sparsely been covered by georeferenced data. Therefore, the current geographical distribution limits of these species are not well documented. The Dermacentor maps presented here should help to fill this serious gap. For this purpose not only historical datasets from Ukraine and Russia were digitized, but numerous recently published tick locations from the entire distribution area in Eurasia were compiled. This renders not only distinctly improved $D$. reticulatus and $D$. silvarum maps, but also a database, usable for modelling of tick habitats and the occurrence of tick-borne diseases vectored by these species.

Particular attention was paid to the climate adaptations of the two herein investigated tick species. As recently done for depicting the distribution of the soft ticks Argas miniatus and Argas persicus (Muñoz-Leal et al. 2018) as well as the Eurasian hard tick H. concinna (Rubel et al. 2018), georeferenced tick sampling sites were superimposed on climate maps.

\section{Materials and methods}

Knowledge on the geographical distribution of D. reticulatus and D. silvarum in Eurasia is based on the existing datasets of Rubel et al. (2016) with 1207 D. reticulatus locations, and 181 D. silvarum locations compiled by Zhang et al. (2019). Two locations were removed from the dataset published by Rubel et al. (2016). The first was in southern Portugal, where according to Santos-Silva et al. (2011) no D. reticulatus occur. The second location contained a wrong coordinate. The original dataset of Zhang et al. (2019) comprises geographical coordinates of 404 (221 without duplicates) D. silvarum locations in China collected during the period 1954-2017. These tick locations were classified into four different levels according to their geographic scales and administrative levels (1=provincial, $2=$ prefectural, $3=$ county, $4=$ township or finer). A total of 41 locations was excluded, which reduces the number of $D$. silvarum locations taken from Zhang et al. (2019) down to 180. In order to supplement these already existing two data sets, a comprehensive literature research was carried out. It refers mainly to those studies in which georeferenced findings were documented. Exceptions were made when sufficient information on the locations or printed maps were available as a basis for digitization. According to Table 1 the following numbers of D. reticulatus locations were incorporated: 10 in Austria, 2 in Bosnia and Herzegovina, 21 in Croatia, 17 in 
Table 1 Number, accuracy (low, medium, high and unspecified), and country of georeferenced Dermacentor reticulatus sampling sites compiled in this study

\begin{tabular}{|c|c|c|c|}
\hline No. & Acc. & Country & References \\
\hline 10 & $\mathrm{~m}$ & Austria & Hodžić et al. (2017b) \\
\hline 1 & 1 & Bosnia & Krčmar et al. (2014) \\
\hline 1 & $\mathrm{~h}$ & Bosnia & Hodžić et al. (2017a) \\
\hline 2 & $\mathrm{~h}$ & Croatia & Radzijevskaja et al. (2015) \\
\hline 19 & $\mathrm{~h}$ & Croatia & Krčmar (2019) \\
\hline 7 & $\mathrm{~m}$ & France & René-Martellet et al. (2015) \\
\hline 2 & $\mathrm{~m}$ & France & Michelet et al. (2016) \\
\hline 8 & 1 & France & LK \\
\hline 14 & 1 & Germany & Pluta et al. (2010) \\
\hline 10 & 1 & Germany & Schreiber et al. (2014) \\
\hline 4 & $\mathrm{~h}$ & Germany & Kohn et al. (2019) \\
\hline 3 & $\mathrm{~h}$ & Germany & OK \\
\hline 9 & $\mathrm{~m}$ & Hungary & Hornok et al. (2014) \\
\hline 1 & $\mathrm{~h}$ & Italy & Genchi et al. (2015) \\
\hline 6 & $\mathrm{~h}$ & Italy & Olivieri et al. (2016) \\
\hline 1 & $\mathrm{~h}$ & Italy & Olivieri et al. (2017) \\
\hline 45 & 1 & Kazakhstan & Amirova et al. (1989) \\
\hline 10 & 1 & Moldova & Movila et al. (2006) \\
\hline 3 & $\mathrm{~h}$ & Netherlands & Hofmeester et al. (2016) \\
\hline 23 & 1 & Poland & Zygner et al. (2009) \\
\hline 13 & $\mathrm{~h}$ & Poland & Kubiak et al. (2018) \\
\hline 11 & 1 & Portugal & Santos-Silva et al. (2011) \\
\hline 1 & 1 & Russia & Ulyanova et al. (1969) \\
\hline 1 & 1 & Russia & Matushchenko et al. (1993) \\
\hline 3 & 1 & Russia & Evstaf'ev (2001) \\
\hline 2 & 1 & Russia & Filippova and Stekolnikov (2007) \\
\hline 2 & 1 & Russia & Shpynov et al. (2008) \\
\hline 4 & $\mathrm{~m}$ & Russia & Gubeidullina et al. (2009) \\
\hline 2 & 1 & Russia & Samoilenko et al. (2011) \\
\hline 26 & 1 & Russia & Tohov et al. (2013) \\
\hline 13 & $\mathrm{~h}$ & Russia & Belova et al. (2014) \\
\hline 1 & $\mathrm{~m}$ & Russia & Dedkov et al. (2014) \\
\hline 8 & 1 & Russia & Kholodilov et al. (2014) \\
\hline 50 & 1 & Russia & Obert et al. (2015) \\
\hline 6 & 1 & Russia & Shchuchinova et al. (2015) \\
\hline 4 & 1 & Russia & Shamsutdinov et al. (2015) \\
\hline 4 & 1 & Russia & Volkov and Bessolytsina (2015) \\
\hline 30 & 1 & Russia & Kozlova et al. (2016) \\
\hline 22 & 1 & Russia & Norkina (2016) \\
\hline 1 & 1 & Russia & Milintsevich et al. (2016) \\
\hline 7 & $\mathrm{~h}$ & Russia & Romanenko et al. (2017) \\
\hline 22 & $\mathrm{~m}$ & Russia & Yankovskaya et al. (2017) \\
\hline 1 & 1 & Russia & Kirillova and Kirillov (2018) \\
\hline 3 & 1 & Russia & Korzikov et al. (2018) \\
\hline 4 & $\mathrm{~m}$ & Russia & Bakhtushkina (2019) \\
\hline 2 & $\mathrm{~h}$ & Russia & Turebekov et al. (2019) \\
\hline
\end{tabular}


Table 1 (continued)

\begin{tabular}{llll}
\hline No. & Acc. & Country & References \\
\hline 1 & 1 & Serbia & Jurišić et al. (2012) \\
1 & 1 & Serbia & Pavlović et al. (2016) \\
5 & h & Slovakia & Radzijevskaja et al. (2015) \\
413 & 1 & Soviet Union & Kulik and Vinokurova (1983b) \\
12 & h & Spain & Barandika et al. (2011) \\
5 & 1 & Spain & LK \\
1 & h & Spain & Remesar et al. (2019) \\
1 & 1 & Switzerland & Eichenberger et al. (2015) \\
120 & 1 & Ukraine & Hightower et al. (2014) \\
1207 & u & European Countr. & Rubel et al. (2016) \\
2188 & - & Total & \\
\hline
\end{tabular}

Sites not referenced here were provided by the authors OK ( 3 sites in Germany) and LK (5 sites in Spain, 8 sites in France)

France, 31 in Germany, 9 in Hungary, 8 in Italy, 45 in Kazakhstan, 10 in Moldova, 3 in the Netherlands, 36 in Poland, 11 in Portugal, 219 in Russia, 2 in Serbia, 413 in the former Soviet Union, 18 in Spain, 1 in Switzerland, and 120 in Ukraine. The digitized D. silvarum locations are listed in Table 2 and composed as follows: 214 in China, 10 in Mongolia, 85 in Russia, and 213 in the former Soviet Union.

As depicted in the Tables 1 and 2, the majority of the references considered were published during the period 2010-2019. Contrary to an increasing number of Dermacentor studies in countries of the European Union, sparsely populated regions of Eurasia are not sufficiently covered by existing studies. Thus, data or handdrawn maps from older studies are still relevant even if they had to be digitized before they could be added to the new Dermacentor maps. These include above all the two maps by Kulik and Vinokurova (1983a, b), without which a good coverage of the countries of the former Soviet Union would not be possible. The same is true for Ukraine, for which Hightower et al. (2014) compiled serveral tick maps in his master thesis. These tick maps are based on data of the period 1940-2008 provided by the CSES (Central Sanitary Epidemiological Station) bacterial archives in Kyiv, Ukraine (Hightower 2012). Some German Dermacentor locations mapped by Pluta et al. (2010) are given in detail in the PhD thesis of Pluta (2011). On the other hand, the detailed map of the Russian Tula region (Kozlova et al. 2016) contained too many $D$. reticulatus locations for the maps compiled here, so that only 30 randomly selected locations of the period 2003-2013 were used.

Digitized locations, of course, are generally of lower accuracy than locations described by geographical coordinates determined by GPS in the field. To provide evidence of this, accuracy measures were given for all data referenced in Tables 1 and 2 in accordance with the scheme applied by Rubel et al. (2014, 2016, 2018). It is distinguished between high (h), medium (m), low (l) and unspecified (u) accuracies. The latter has been applied here only to the transnational record of Rubel et al. (2016) that contains tick locations of all accuracy levels. A high accuracy $( \pm 0.1 \mathrm{~km})$ was allocated to coordinates given in degrees, minutes and seconds or in decimal degrees with at least $4-5$ relevant decimal places. A medium accuracy $( \pm 1 \mathrm{~km})$ was assumed for coordinates given in degrees and minutes or in decimal degrees with at least 2-3 relevant decimal places. A medium accuracy was also assumed for ticks collected from 
Table 2 Number, accuracy (low, medium, high and unspecified), and country of georeferenced Dermacentor silvarum sampling sites compiled in this study

\begin{tabular}{|c|c|c|c|}
\hline No. & Acc. & Country & References \\
\hline 1 & $\mathrm{~h}$ & China & Yu et al. (2010) \\
\hline 13 & $\mathrm{~h}$ & China & Jiang et al. (2011) \\
\hline 3 & 1 & China & Liu et al. (2016) \\
\hline 8 & 1 & China & Sun et al. (2017) \\
\hline 2 & $\mathrm{~m}$ & China & Han et al. (2018) \\
\hline 2 & 1 & China & Jia et al. (2018) \\
\hline 1 & 1 & China & Wang et al. (2018) \\
\hline 2 & 1 & China & Zhang et al. (2018) \\
\hline 1 & 1 & China & Meng et al. (2019) \\
\hline 1 & 1 & China & Zhao et al. (2019) \\
\hline 180 & 1 & China & Zhang et al. (2019) \\
\hline 10 & 1 & Mongolia & Hightower et al. (2012) \\
\hline 6 & 1 & Russia & Kolonin et al. (1984) \\
\hline 2 & 1 & Russia & Filippova and Apanaskevich (2005) \\
\hline 2 & 1 & Russia & Danchinova et al. (2007) \\
\hline 3 & 1 & Russia & Balakhonov et al. (2012) \\
\hline 1 & 1 & Russia & Danchuk et al. (2012) \\
\hline 1 & $\mathrm{~m}$ & Russia & Bolotova et al. (2014) \\
\hline 2 & $\mathrm{~m}$ & Russia & Rar et al. (2014) \\
\hline 1 & 1 & Russia & Gordeiko (2015) \\
\hline 1 & 1 & Russia & Kurganova et al. (2015) \\
\hline 19 & 1 & Russia & Obert et al. (2015) \\
\hline 7 & 1 & Russia & Shchuchinova et al. (2015) \\
\hline 1 & 1 & Russia & Zvereva et al. (2015) \\
\hline 2 & $\mathrm{~m}$ & Russia & Bogdanov et al. (2017) \\
\hline 1 & $\mathrm{~m}$ & Russia & Lubova et al. (2017) \\
\hline 7 & 1 & Russia & Chistyakova et al. (2018) \\
\hline 4 & 1 & Russia & Igolkina et al. (2018) \\
\hline 2 & 1 & Russia & Leonova et al. (2018) \\
\hline 4 & $\mathrm{~m}$ & Russia & Pukhovskaya et al. (2018) \\
\hline 4 & $\mathrm{~h}$ & Russia & Seryodkin et al. (2018) \\
\hline 14 & $\mathrm{~h}$ & Russia & Kholodilov et al. (2019) \\
\hline 1 & 1 & Russia & Doroshchenko et al. (2019) \\
\hline 213 & 1 & Soviet Union & Kulik and Vinokurova (1983a) \\
\hline 522 & - & Total & \\
\hline
\end{tabular}

animals or humans and for coordinates digitized from local maps. Coordinates digitized from regional maps were classified as low-accuracy data $( \pm 10 \mathrm{~km})$. After data collection, homogenization of the associated geographical coordinates (conversion to decimal degrees with 4 digits), and homogenization of the accuracy measures, the final dataset was compiled by eliminating further duplicate entries.

To visualize the geographical distribution of D. reticulatus and D. silvarum, the georeferenced locations were plotted on terrain maps (OpenStreetMap contributors 2017). They show the distribution patterns of the two tick species determined by continental-scale 
mountain ranges like the Himalayas and surrounding steppes and deserts. The latter were also depicted in a second type of maps, where the tick locations were plotted on climate maps. Therefore, new global maps of the Köppen-Geiger climate classification (Rubel and Kottek 2010) were calculated from the latest version of temperature fields provided by the Climatic Research Unit (CRU) of the University of East Anglia and precipitation fields from the Global Precipitation Climatology Centre (GPCC) at the German Weather Service. Compared to Köppen-Geiger maps used in the previous study by Rubel et al. (2018), three times more Chinese precipitation measurements (Andreas Becker (GPCC), personal communication) lead to a significantly improved climate classification of important $D$. silvarum distribution areas. Generally, the Köppen-Geiger climate classification is based on 31 climate classes described by a three-letter code. The first letter distinguishes between different types of vegetation of the equatorial zone (A), the arid zone (B), the warm temperate zone (C), the boreal or snow zone (D), and the polar or ice zone (E). The second letter in the classification considers precipitation (e.g. Cf for warm temperate and precipitation all year round) and the third letter considers air temperature (e.g. Cfb warm temperate, precipitation all year round and warm summer).

The climate map (version December 2018) is provided on http://koeppen-geiger.vuwien.ac.at/present.htm together with the underlying digital data and an R code (R Development Core Team 2019) for reading and visualization. The gridded climate classification is available with a spatial resolution of 5 arcmin and representative for the 25-year period 1986-2010. It was calculated from downscaled, i.e. disaggregated (Rubel et al. 2017), CRU V4.03 temperature and GPCC V8 precipitation fields as described by Kottek et al. (2006). With this dataset, each tick location can be related to a specific climate class in order to calculate a histogram. Recent application of this so-called Köppen profile were, for example, presented by Grímsson et al. (2018) and Rubel et al. (2018).

\section{Results and discussion}

Figure 1 depicts a map of the entire distribution areas of the two tick species $D$. reticulatus and D. silvarum as well as three high resolution maps of selected regions with findings of these ticks.

The distribution of georeferenced $D$. reticulatus locations within the geographic range of $-9-88^{\circ} \mathrm{E} / 39-60^{\circ} \mathrm{N}$ is shown in Fig. 1a. Thus, the latitudinal belt, in which D. reticulatus occurs in Eurasia, is $5^{\circ}$ wider than recently described for only Europe (Rubel et al. 2016). The northernmost location of D. reticulatus is in Russia at $68.96^{\circ} \mathrm{E} / 59.73^{\circ} \mathrm{N}$, which is confirmed by a second nearby location. The southernmost location might be in Armenia at $46.03^{\circ} \mathrm{E} / 39.21^{\circ} \mathrm{N}$. Both limits were taken from the dataset compiled by Kulik and Vinokurova (1983b). Please note that a total of 5 remote sites from this dataset were removed as part of the reliability check. Two of them were marked by the authors themselves as lying outside the common range of $D$. reticulatus. At 3 sites in Uzbekistan $D$. reticulatus seems to have been confused with the common species Dermacentor marginatus. In addition to the reliability check of the tick locations, special attention was paid to closing data gaps in previous distribution maps. These include the first georeferenced locations in Italy, where $D$. reticulatus were collected from vegetation at 8 locations in the Lombardy region of northern Italy (Genchi et al. 2015; Olivieri et al. 2016, 2017). Also in France, new locations expand the documented distribution area of D. reticulatus. René-Martellet et al. (2015) published the first findings on the Mediterranean island 

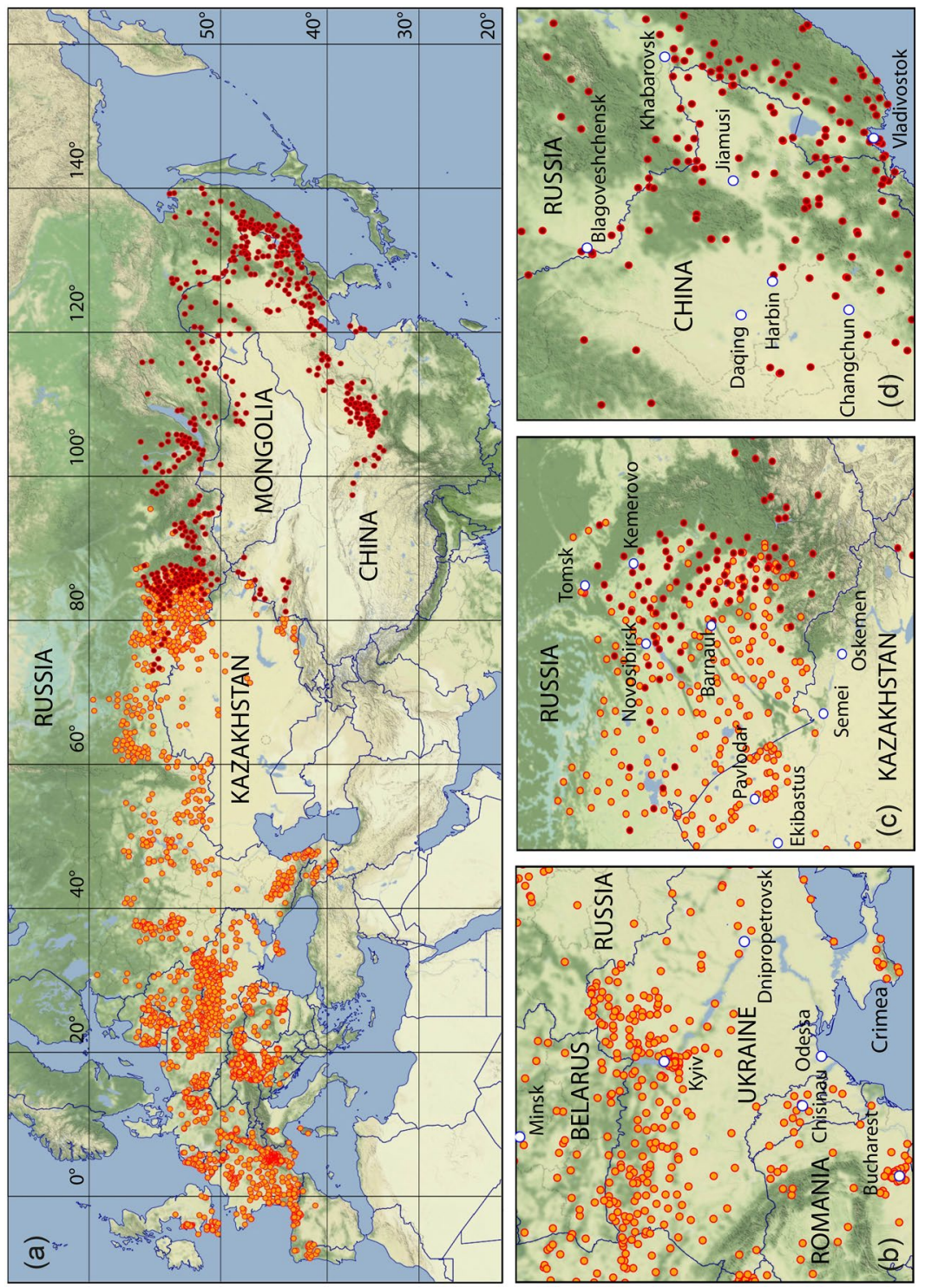

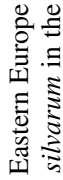

$\Xi 0$

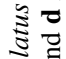

莡

in

- प्य

.ే̊

芑

党

$\frac{10}{0}$

类

芯?

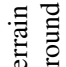

可

ิㅗ 옹

ర్

를 코

卷

芯

จิ $\Xi$

을

종

है

ธิ

约

เ

믘

(2)

苞节芯

今

ㄴㅇㅛ

记

음

ᄒิ

됭 당

ㄷำ

है

渮焉

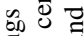

齐

近

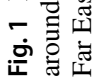


Corsica and Michelet et al. (2016) on the Atlantic islands Belle-Île-en-Mer, an island off the coast of Western France. In Germany, 30 new locations were documented, including the first findings of $D$. reticulatus at the German Baltic coast in the port of Rostock at $12.14^{\circ} \mathrm{E} / 54.15^{\circ} \mathrm{N}$. This reference confirms the continuous encroachment of D. reticulatus to the north during the past 2-3 decades (Paulauskas et al. 2015). It also indicates an almost continuous occurrence of D. reticulatus on the Atlantic and Baltic coasts of Europe, reaching from northern Portugal to southern Latvia. An exception is Scandinavia, where no D. reticulatus have been found on vegetation (Kjaer et al. 2019), although 21 adult male $D$. reticulatus were found on a migrating Golden jackal (Canis aureus) in Denmark (Klitgaard et al. 2017). However, this seems to be a rare case of diversion rather than an indication for a new established occurrence area of $D$. reticulatus. Interesting that only males were found, which might stay on a host for longer than females. Further D. reticulatus locations have been documented in the south of England and in Wales (Medlock et al. 2017). The sparse information on the occurrence of $D$. reticulatus in the Western Balkans has been supplemented by 25 locations in Bosnia and Herzegovina, Croatia, and Serbia (Table 1). Many locations are known from Poland, Belarus, and Ukraine (Fig. 1b). Accordingly, D. reticulatus is widespread in the entire north of Ukraine, but also in the south of the Crimean peninsula (Hightower 2012). It is also widespread in the European part of Russia from the Caucasus in the south to some $100 \mathrm{~km}$ north of Moscow. In the east, the range extends over the north and east of Kazakhstan (Amirova et al. 1989) to Western Siberia, where the Tom river from Tomsk to Kemerovo and further to Novokuznetsk forms the main natural boundary (Fig. 1c). Three remote $D$. reticulatus locations were recorded in the map of Kulik and Vinokurova (1983b), where a location east of Krasnoyarsk at 95.4 ${ }^{\circ} \mathrm{E} / 55.6^{\circ} \mathrm{N}$ marks the easternmost location. However, these historical locations could not be confirmed in recent studies.

The distribution of georeferenced $D$. silvarum locations in the range of $73-140^{\circ} \mathrm{E} / 34-57^{\circ} \mathrm{N}$ is also shown in Fig. 1a, where it overlaps with $D$. reticulatus in the region $73-88^{\circ} \mathrm{E}$, centered around Novosibirsk. The locations digitized from the map of Kulik and Vinokurova (1983a) show that the South Russian distribution area of $D$. silvarum extends to the Pacific coast. More than 20 recent publications confirm the distribution in the Altai region and in the Far East, including the region around Lake Baikal and the north of Mongolia. Among them is the recent study by Obert et al. (2015), which depicts details on the overlapping distribution range of D. reticulatus and D. silvarum in the Altai region (Fig. 1c). However, most pertinent publications provide D. silvarum locations with low accuracy. Therefore, the high accuracy geographical coordinates of the locations provided by Seryodkin et al. (2018) and Kholodilov et al. (2019) must be highlighted. They allow a correct assignment of habitats and climates preferred by D. silvarum. In the Far East, the Russian locations seamlessly connect to the Chinese D. silvarum locations Jiang et al. (2011). Figure 1d shows that the distribution area of $D$. silvarum extends across the whole of north-eastern China to the capital Beijing and beyond. The eastern and/or southern border forms the Pacific in this region. Chinese D. silvarum findings were also reported from the border to the Democratic People's Republic of Korea. According to the prevailing climate it can be assumed that $D$. silvarum is also endemic in the Democratic People's Republic of Korea, although there is no evidence for this in the literature. In north-central China, especially in the provinces Heibei, Shanxi, and Shaanxi, D. silvarum is also common. Here, the southernmost distribution limit of D. silvarum is defined by a location at $108.8^{\circ} \mathrm{E} / 33.8^{\circ} \mathrm{N}$. However, some historical remote locations from the data compilation of Zhang et al. (2019) were not considered in this study as they occur in climates not typical for D. silvarum and 
have not been confirmed, as yet. Locations of $D$. silvarum have also been documented in the north-west of China, in the province of Xinjiang, bordering the distribution area of D. reticulatus in Kazakhstan.

Of particular interest is the comparison of the climate adaptations of D. reticulatus and D. silvarum, which mainly determine the global distribution of each of the two tick species. For this purpose, the tick locations were superimposed on the Köppen-Geiger climate classification map and a frequency distribution of each tick's occurrence in different climates was compiled.

Figure 2 shows the climate classification map together with the Köppen profile for $D$. reticulatus. The latter is a histogram showing the frequency of tick occurrence reported for different climate classes. Two peaks are related to the following climates: warm temperate with precipitation all year round $\mathrm{Cf}(57 \%)$ and boreal with precipitation all year round Df (40\%). Thus, a total of $97 \%$ of all D. reticulatus locations was reported in these climates, and it is evident that $D$. reticulatus prefers precipitation all year round. In regions with winter temperatures below zero degrees Celsius, D. reticulatus thus benefits from a protective snow cover that is hardly available in climates with dry winters. The remaining locations were reported in cold steppes BSk (1\%) as well as in Mediterranean climates Csa and Csb (2\%). These occurrences of D. reticulatus are either due to favourable local climatic conditions or to misidentification. Please note that the Köppen-Geiger climate classification distinguishes between warm temperate (C) and boreal (D) climates only by means of temperature. Warm temperate $\mathrm{C}$ climates are defined for a temperature range of $-3{ }^{\circ} \mathrm{C}<T_{\text {min }}<+18^{\circ} \mathrm{C}$, boreal climates for $T_{\text {min }} \leq-3{ }^{\circ} \mathrm{C}$, where $T_{\min }$ is the mean temperature of the coldest month of the year (Kottek et al. 2006). A more detailed analysis reveals that warm summers might have a positive influence on the occurrence of $D$. reticulatus. This might also explain the invasion of parts of northern Germany and the Netherlands by this species as well as its encroachment to the north in the Baltic States in the past 2-3 decades. Approximately $75 \%$ D. reticulatus locations are related to climates with warm summers $\mathrm{Cfb}$ and $\mathrm{Dfb}$. Regions with warm summers are defined for a maximal monthly temperature of $T_{\max }<22^{\circ} \mathrm{C}$ and at least four months with $T_{m o n} \geq 10^{\circ} \mathrm{C}$ (Kottek et al. 2006). Only $25 \%$ of the documented $D$. reticulatus locations are related to climates with hot summers. This makes perfectly sense when taking the necessity for $D$. reticulatus that the development from oviposition to the F1 adult generation has to take place within only one season (Balashov 1972; Kahl and Dautel 2013) and might be one limiting factor for the northernmost distribution of that tick species. This goes also along the fact that D. reticulatus is not a forest inhabitant in central Europe, but prefers more open terrains where the soil surface is more sun-exposed (and therefore warmer) in the summer than the forest floor.

Figure 3 shows the climate classification map together with the Köppen profile for $D$. silvarum with two major peaks related to the following climates: boreal with precipitation all year round Df (30\%) and boreal winter dry (60\%). However, D. silvarum makes no claims to the summer temperatures, which can range from cool to hot. Climates with hot summers are defined for maximal monthly temperatures of $T_{\max } \geq 22^{\circ} \mathrm{C}$. Climates with summer temperatures below those defined for hot and warm summers are characterized by cool summers and cold winters if $T_{\min }>-38 \circ \mathrm{C}$, otherwise they are called extremely continental (Kottek et al. 2006). Almost $90 \%$ of all D. silvarum locations are related to boreal Df and Dw climates. The remaining locations were classified as cold steppe BSk (7\%) and warm temperate climate with dry winters and hot summers Cwa (3\%), exclusively observed in the Chinese distribution area of D. silvarum. However, D. silvarum does not occur in Cwa climates and also the occurrence in cold steppes is overestimated in the frequency diagram presented in Fig. 3. This can be explained by the rapid climate change 

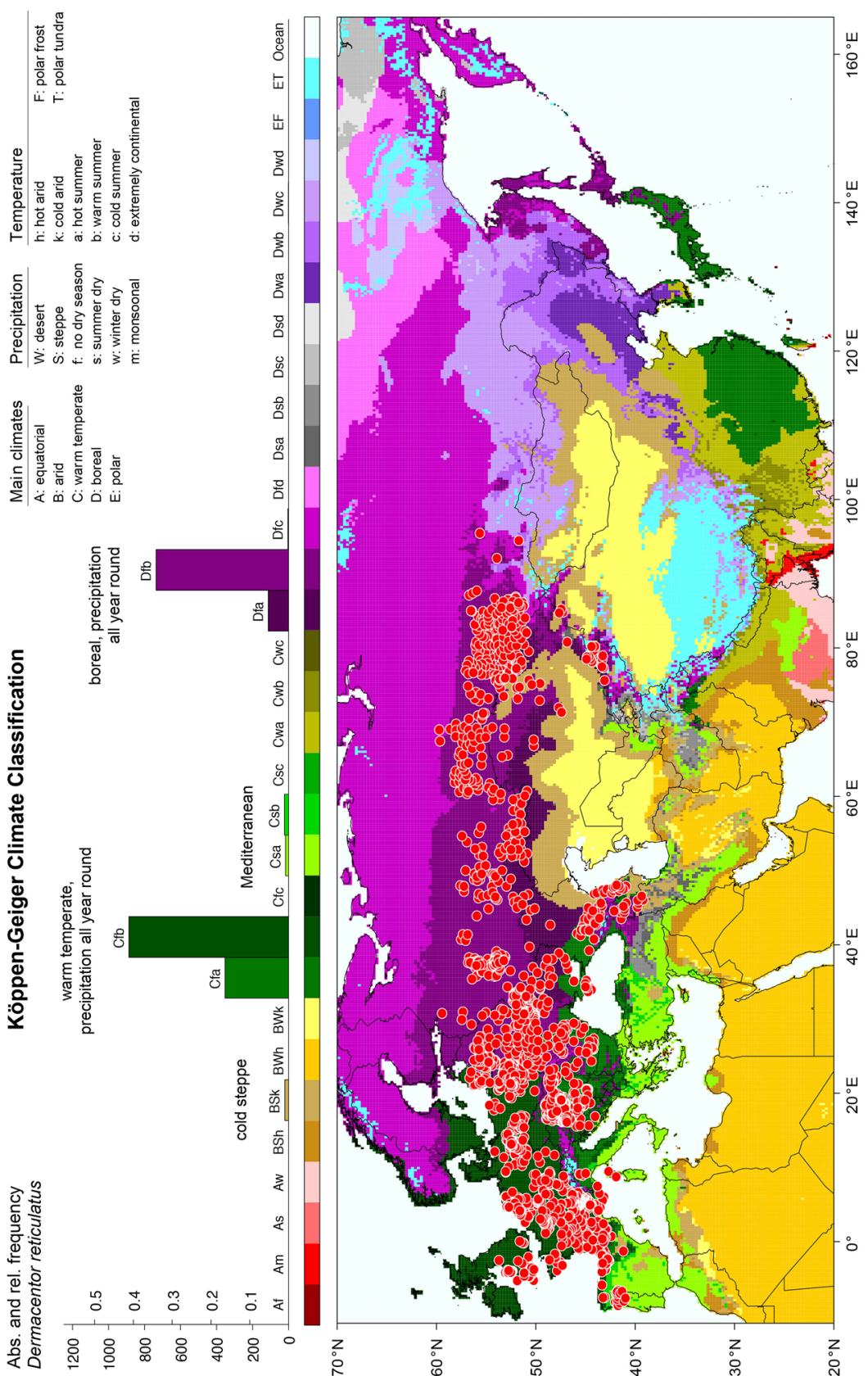

这

:

过言

पै

을

言 줄

:

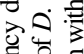

要

ㄱ.

帝官

(2)

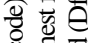

.

훈

\&

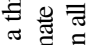

즈응 응

플 륭

券

ธี 흘

을

땡

尊 貝

눙

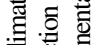

跑

.

(5)

른

:

急

范

종

宅

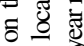

흘

루

言

言主

논

훻

.

छั

है

ปั

$\begin{array}{ll} & \\ 0 & \\ 0 & 0 \\ 0 & 0\end{array}$

层

实

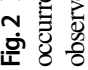




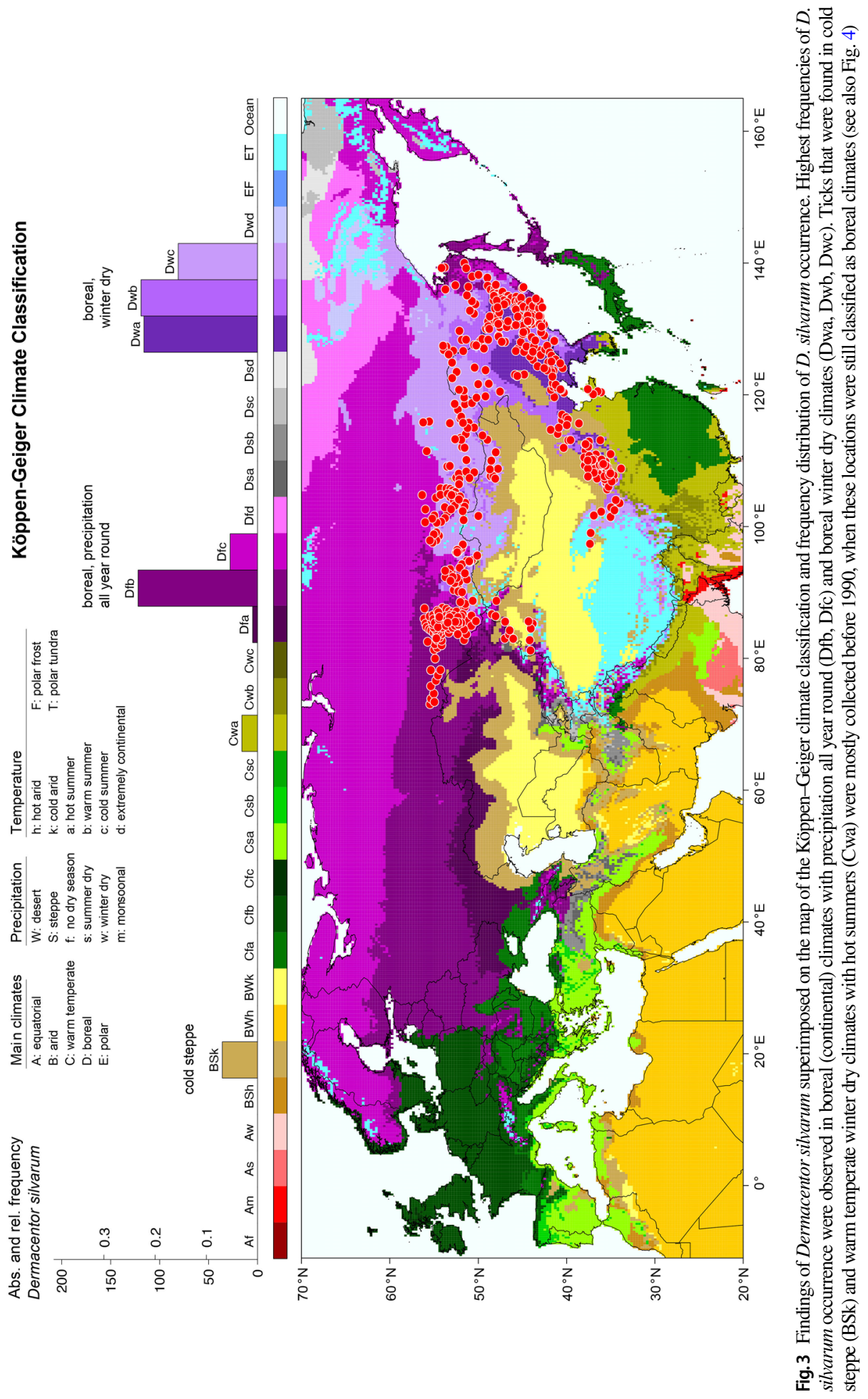


in central China. For this purpose, a second map of the Köppen-Geiger climate classification for the period 1956-1980 was calculated and compared with that of 1986-2010.

Figure 4 shows a section of these maps centered around the coordinates $110.5^{\circ} \mathrm{E} / 38.0^{\circ} \mathrm{N}$ southwest of Beijing. The boreal winter dry climates Dwa, Dwb and Dwc, suitable for $D$. silvarum, are surrounded in the north by the cold steppe climate BSk and the desert climate BWk of Inner Mongolia, and in the south by the warm temperate climate Cwa. As climate change progressed, this region became warmer and drier and therefore less suitable for D. silvarum. The boreal climates were replaced by cold steppes (BSk) in the north, and by warm temperate climate with hot summers (Cwa) in the south. All those D. silvarum found in the Cwa climate of the map representative for the period 1986-2010, were already collected before 1990 in the-at that time still-boreal climates. This is shown by the comparison of the climate map 1956-1980 with all ticks collected from 1954 to present with the climate map 1986-2010, in which only those ticks collected after 1990 are represented. An exception are the $4 \mathrm{D}$. silvarum locations from the Chinese province Shandong $\left(120^{\circ} \mathrm{E} / 36^{\circ} \mathrm{N}\right.$, Fig. 3). Here, too, the former Dwa climate was replaced by the Cwa climate, but D. silvarum were also found during the period 2015-2017. Regardless, most records in central-northern China are from more than 30 years ago, which is why no exact coordinates are available. In addition, many ticks were collected from animals, which is associated with further uncertainties regarding their exact location. Especially at the borders of climate zones this leads to the fact that $D$. silvarum locations may erroneously be assigned to the arid steppe or warm temperate climates. In this context, the finding of 21 D. reticulatus males on a Golden jackal in western Denmark some hundred kilometres away from the nearest known place of occurrence of that species (Klitgaard et al. 2017) is very interesting. This example shows that such cases may happen but that it is necessary to carefully differentiate between the core distribution of a species where it goes through the whole life cycle and other areas-possibly with unsuitable climate-where that species may occur sporadically in limited numbers for a short period of time. In any case, however, it can be stated that $D$. silvarum is better adapted to arid regions as well as to hot summers than $D$. reticulatus. This can also be seen when comparing climate diagrams typical of $D$. reticulatus locations in Kyiv and D. silvarum locations in Beijing (Fig. 5).

In summary, it was shown that $D$. reticulatus occurs in warm temperate or boreal climates with precipitation all year round and warm summers. In contrast, D. silvarum occurs preferentially in boreal (continental) climates, whereby there must only be sufficient precipitation in the summer half-year. The fact that D. silvarum is particularly well adapted to cold winter temperatures is shown by the lower lethal temperatures (50\% survival) for larvae and nymphs of approximately $-16^{\circ} \mathrm{C}$ and for adults of $-20^{\circ} \mathrm{C}$. The temperatures, at which $D$. silvarum body fluids spontaneously freeze, was determined to be $-20^{\circ} \mathrm{C}$ and $-24^{\circ} \mathrm{C}$, respectively (Wang et al. 2017). The occurrence of D. silvarum in dry steppes or in warm temperate climates can be frequently attributed to the fact that these climates were boreal at the time the historical tick locations were reported. Related frequencies of $D$. silvarum occurrence (BSk and Cwa climates) in the histogram in Fig. 3 are therefore mainly statistical artefacts. In the interpretation of the absolute and relative abundances of the climates suitable for ticks, it must also be considered that these could be biased due to the presence or absence of local tick research groups.

Because the geographical distribution of vector tick species is particularly important in connection with tick-borne diseases, an overview of pathogens detected in adult questing D. reticulatus ticks was compiled by Rubel et al. (2016). That table should be extended by TBE virus repeatedly isolated from adult $D$. reticulatus ticks in an endemic area in Germany (Chitimia-Dobler et al. 2019). In this context, also the study on acute canine 


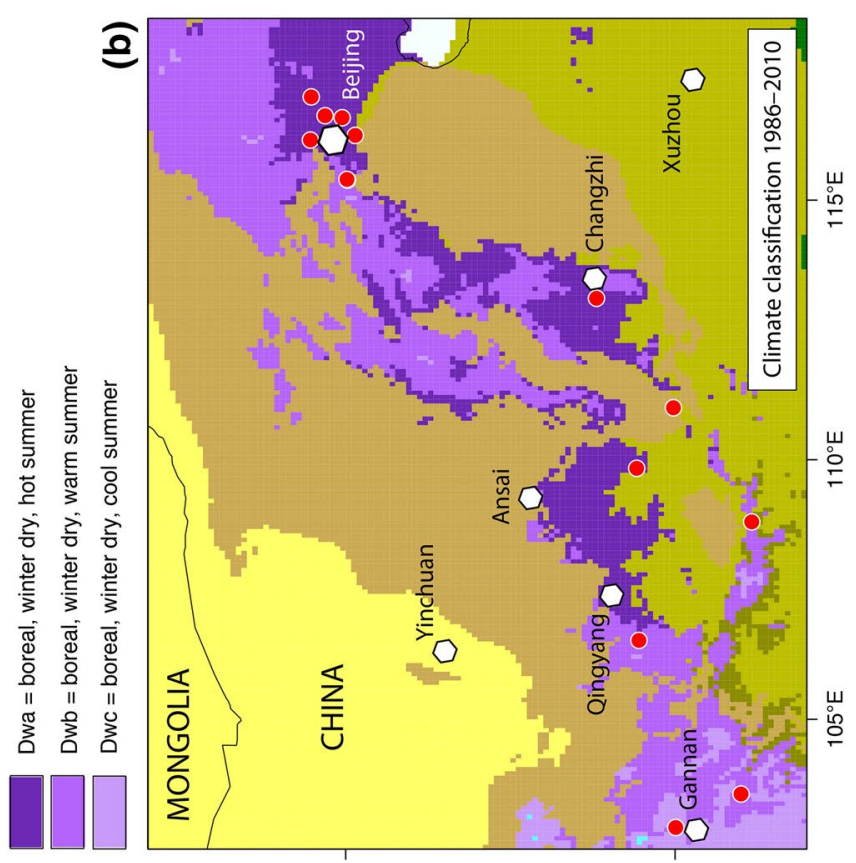

ฮี

๑艹

密

帘 8

䒕 䨠

罗

焉

讨

:

\%

可

寻宅总

ㅎㅇํำ

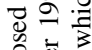

亩密宾

एँ

के

苯司

过 。

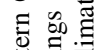

흐음

品:

至

竞芯

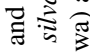

원
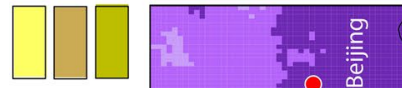

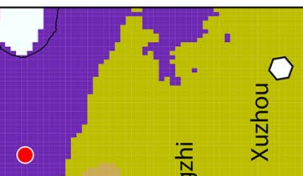
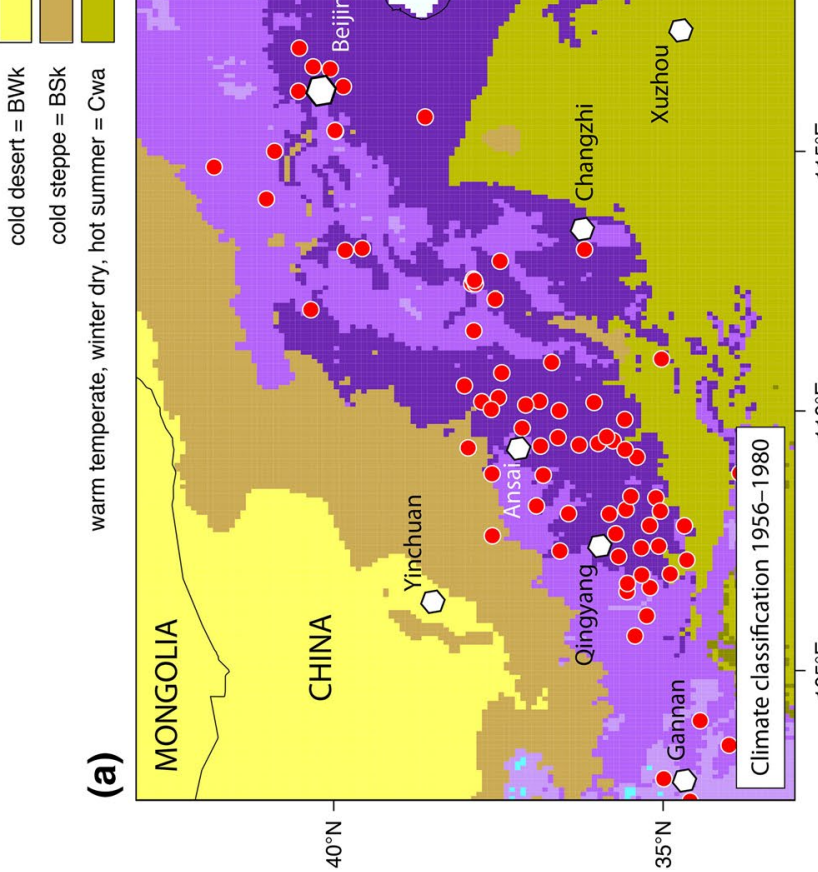

สํํำ

흉응

प्त

잉

을

옹 홍

उ

원

$\$$

흄

额

के

记

弯

ऽ $\Xi$

岁青

오욜

ప

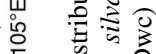
包

ซึ

글

.

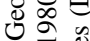

$+1$

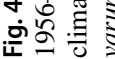


babesiosis in Belgrade (Serbia) is of interest (Janjić et al. 2019). Table 3 provides a summary of the pathogens found in questing D. silvarum. Also in D. silvarum, TBE virus or its RNA was detected in both China (He et al. 2018) and Russia (Kholodilov et al. 2019). In addition, 4 other viruses and numerous pathogenic bacteria and protozoa have been found in D. silvarum. However, the finding of any tick-borne pathogens in questing ticks is no proof of vector competence but at least confirms the state of a carrier. Without proven capability of transmission the vector function of a given tick species for a given pathogen is not substantiated (Kahl et al. 2002). Mere determination of the carrier status of fieldcollected questing ticks is only a very first step to indicate vector competence.

Table 4 summarizes the results of studies which demonstrated vector competence of $D$. reticulatus for various pathogens, i.e. successful transmission experiments with hosts. For example, the studies by Kožuch and Nosek (1971), Alekseev and Chunikhin (1991) and Belova et al. (2013) confirmed the role of D. reticulatus as a vector for the TBE virus. The same applies to $R$. sibirica, the causative agent of North Asian/Siberian tick typhus (Korshunova 1967). Further successful transmission experiments of pathogens from infected ticks to exposed hosts were carried out for the Palma virus (Labuda et al. 1997), Coxiella burnetii (Zhmaeva and Pchelkina 1967b), Anaplasma marginale (Zivkovic et al. 2007), and B. canis (Varloud et al. 2018). According to Balashov (1972) and the European Centre for Disease Prevention and Control (www.ecdc.europa.eu/en/tularaemia/facts), D. reticulatus is also a proven vector of Francisella tularensis, the causative agent of tularaemia. Both transstadial survival and transovarial transmission was demonstrated for Borrelia afzelii (Rudakova et al. 2005), for Anaplasma sp. Omsk (Krasikov et al. 2007), and for Brucella sp. (no mention of the species!) (Rementsova and Khrushcheva 1967) in D. reticulatus, but this alone does not mean that this tick species can transmit these agents to hosts.

Table 5 summarizes successful pathogen transmission studies with $D$. silvarum. The number of studies is much smaller than that for D. reticulatus. TBE virus (Zhmaeva and Pchelkina 1967b), Rickettsia sibirica (Korshunova 1967), and Babesia caballi have been shown to be transmitted by $D$. silvarum. Transstadial survival in D. silvarum was found for Powassan virus (Kruglyak and Leonova 1989), for Rickettsia raoultii (Samoylenko et al. 2013) and for Anaplasma sp. Omsk (Krasikov et al. 2007). Transovarial transmission by $D$. silvarum was demonstrated for $R$. raoultii (Samoylenko et al. 2013) and for Anaplasma sp. Omsk (Krasikov et al. 2007). Although these studies indicate some susceptibility of $D$. silvarum for each of those three agents, the proof of its vector competence for them is still missing. No vector competence of $D$. silvarum could be demonstrated for $B$. garinii (Sun and $\mathrm{Xu}$ 2003). Larval and nymphal $D$. silvarum efficiently acquired spirochaetes from infected hosts, but spirochaetes could no longer be detected from engorged larval and nymphal ticks 1-2 weeks after repletion, and there was no evidence of transstadial passage to the resulting nymphs or adults.

\section{Conclusions and outlook}

Dermacentor reticulatus has been in the focus of research for decades, because it is a long-known proven vector of TBE virus and B. canis (Table 4). Dermacentor silvarum is a proven vector of TBE virus, $R$. sibirica, and $B$. caballi (Table 5). Both Dermacentor species can often be found in considerable numbers in green spaces and parks of large cities. To summarize the current knowledge on the distribution of D. reticulatus and $D$. silvarum, comprehensive datasets of georeferenced tick locations were compiled to draw 


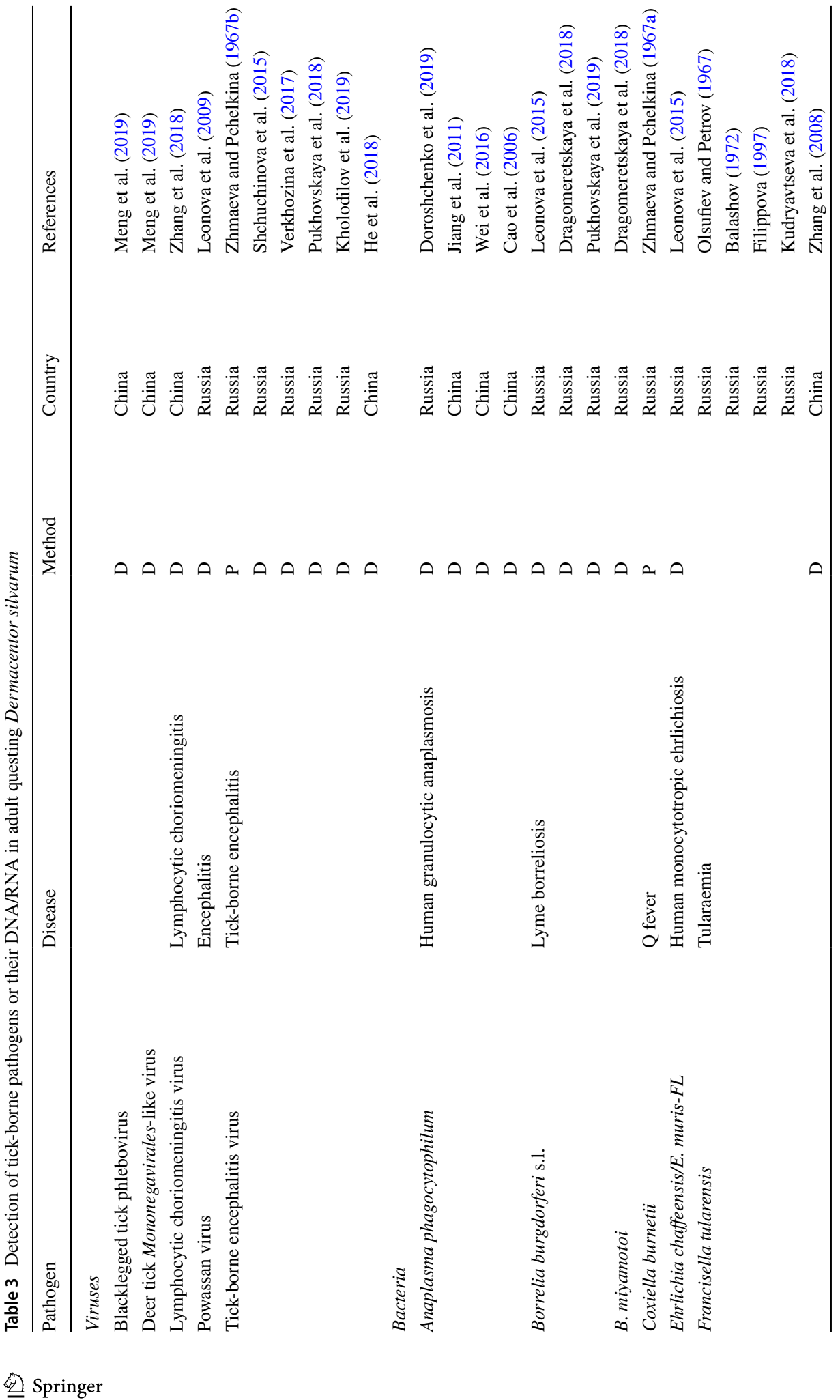




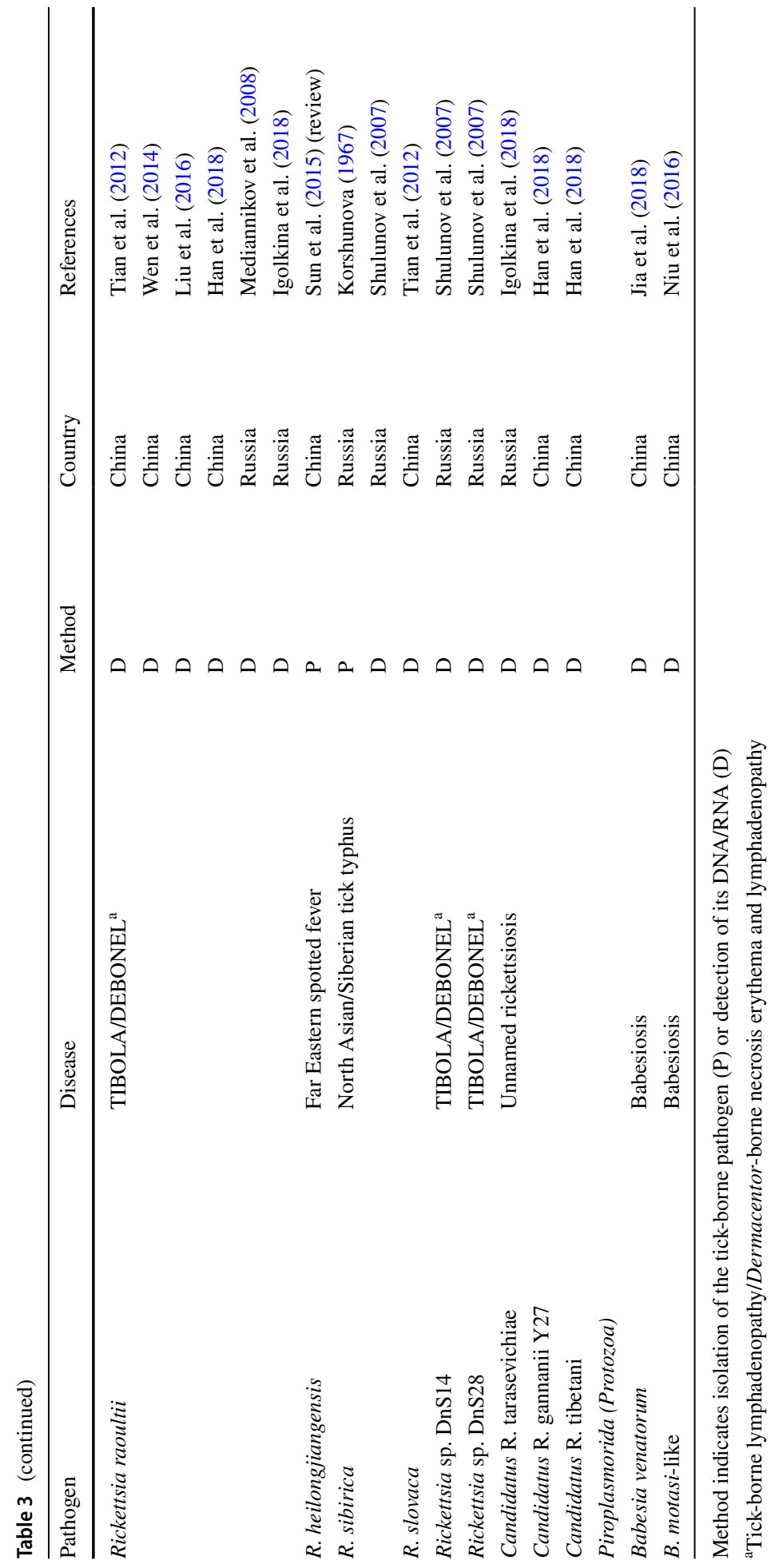




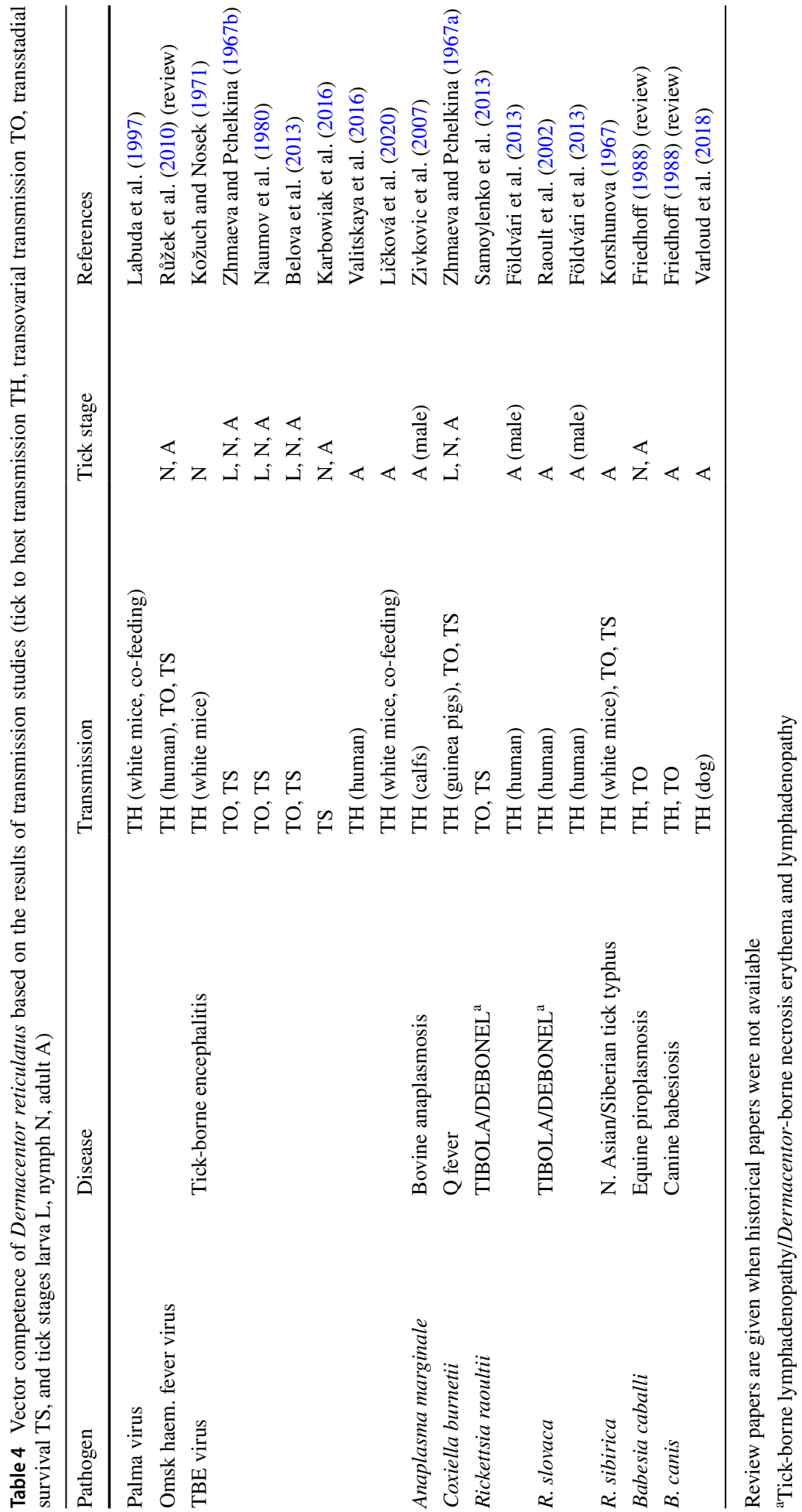




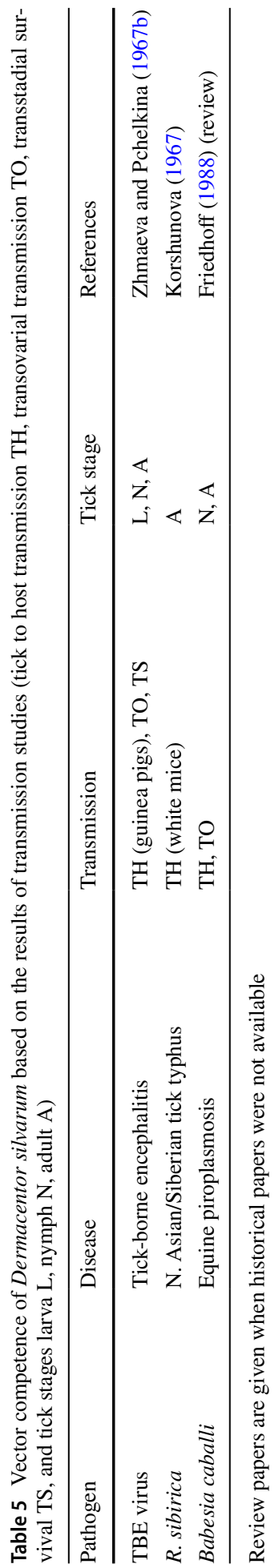



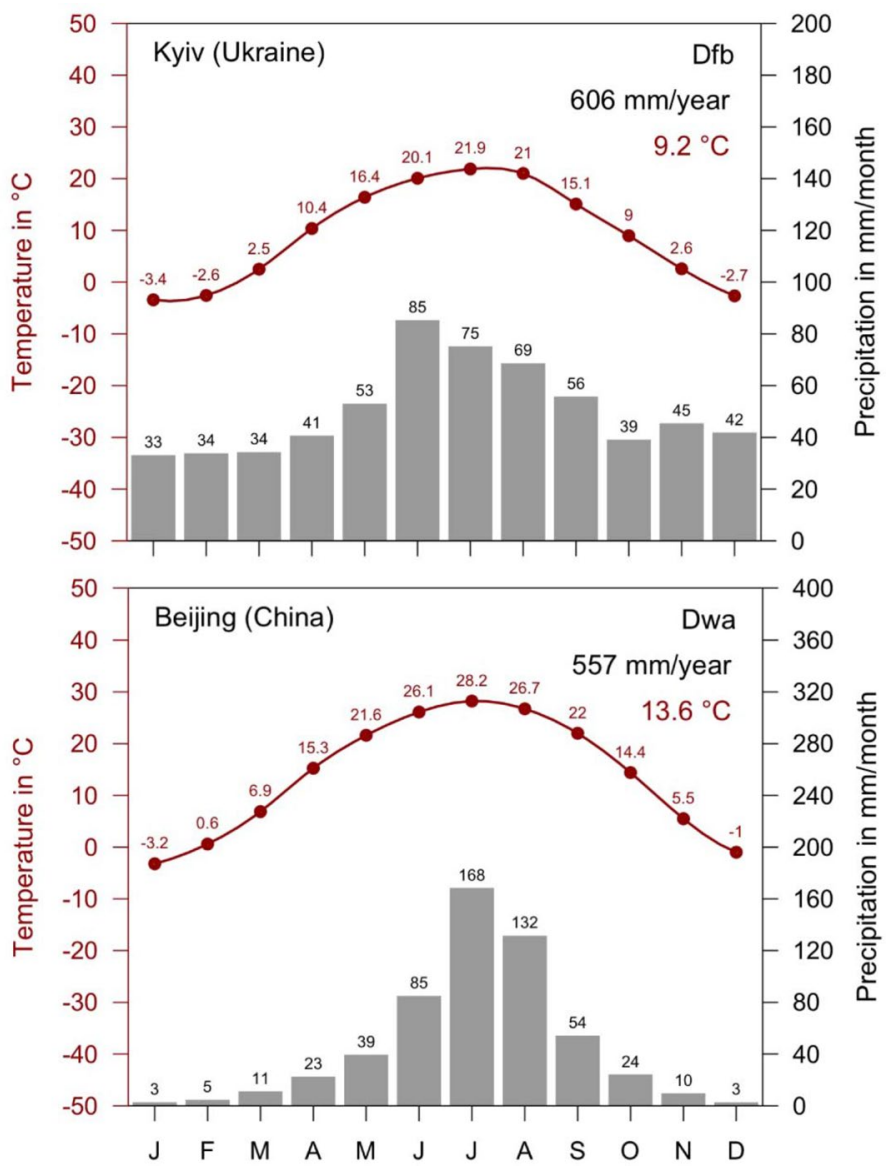

Fig. 5 Climate diagrams for the period 1986-2010. Boreal climates with precipitation all year round and warm summer (Dfb) in Kyiv, Ukraine, typical for Dermacentor reticulatus locations and winter dry with hot summer (Dwa) in Beijing, China, typical for D. silvarum locations

the first geographical maps covering their entire distribution ranges. Although these data collections are one of the most extensive, they have some weak points. For example, there are no data for the Korean Peninsula and for Sakhalin (Kiefer et al. 2010), although $D$. silvarum should occur in both regions. Furthermore, many geographical descriptions do not include coordinates, which is why a high number of locations is known only with low accuracy (Tables 1,2), especially in Asia reported in the Chinese and Russian literature. Only in recent scientific papers (Jiang et al. 2011; Kholodilov et al. 2019) exact geographic coordinates were given. This should be standard in future field studies.

Another problem that should be solved in future studies are reported locations of tick species, which might be unreliable. Especially, determination of Dermacentor species in the Far East before 1980 are questionable. Concerning historical data, Yamaguti et al. (1971) stated in their book Ticks of Japan, Korea, and the Ryukyu Islands that they have not attempted to determine the species of the genus Dermacentor, since there is very little information. The data collection of Zhang et al. (2019) going back to 1954 lists $29 \mathrm{D}$. reticulatus locations in the Chinese province Shaanxi, which appear questionable. The region 
southwest of Beijing, shown in Fig. 4, is much too dry for D. reticulatus in the winter half-year. Since these sites are more than $2000 \mathrm{~km}$ away from the nearest endemic areas of D. reticulatus in Kazakhstan and Russia and were not confirmed by independent working groups, they were not used here. However, they have already been adopted in several literature reviews, which gives the impression of confirmed $D$. reticulatus occurrences in China. This problem can only be finally clarified by a verification of $D$. reticulatus samples from Shaanxi.

Future studies will also have to pay more attention to the assignment of the correct climate to the tick locations. It should be noted that climate data do not have the same high accuracy in large areas of Central Asia, especially in arid and mountainous regions, as in Europe. The reason for this is the climate measurement network, which is not very dense in sparsely populated areas. Most of the Dermacentor locations, which were identified in the climate statistics as arid, could therefore be misclassified due to uncertainties of geographic allocation as well as climate classification. In addition, there is climate change, which also contributes to an uncertainty in determining the suitable climates for the 2 tick species $D$. reticulatus and D. silvarum (Fig. 4). In subsequent studies, the tick locations must therefore be selected according to their date in order to take the exact climate requirements into account. Only then can the georeferenced tick locations be used by species distribution models (SDMs) to determine the impact of climate change on the future distribution of tick species. Previous predictions with SDMs have neglected climate change in the past, which is why they often provide unrealistic future tick distributions.

Although tick-borne agents have often been found in questing adult D. reticulatus and D. silvarum (Table 3), experimental transmission studies are still largely lacking. Linking proved vector competence for certain pathogens and large-scale tick occurrence with tick-borne diseases would strongly support the work of public health authorities. To the authors' knowledge, there is only one paper on this topic. For China, Sun et al. (2017) compiled a national TBE map based on an SDM that uses the distribution of the TBE vectors (I. persulcatus, D. silvarum, H. concinna, and other tick species) as additional predictors. In order to be able to create a similar map for the entire TBE endemic area in Eurasia, the data sets presented here must be expanded at least by the main TBE vectors $I$. ricinus and I. persulcatus. The Central European TBE map, which is based on TBE positive ticks and endothermic mammals (Walter et al. 2020), could also be extended to the entire TBE distribution area with such tick data.

Funding Open access funding provided by University of Veterinary Medicine Vienna.

\section{Compliance with ethical standards}

Conflict of interest The authors declare that they have no conflict of interest.

Open Access This article is licensed under a Creative Commons Attribution 4.0 International License, which permits use, sharing, adaptation, distribution and reproduction in any medium or format, as long as you give appropriate credit to the original author(s) and the source, provide a link to the Creative Commons licence, and indicate if changes were made. The images or other third party material in this article are included in the article's Creative Commons licence, unless indicated otherwise in a credit line to the material. If material is not included in the article's Creative Commons licence and your intended use is not permitted by statutory regulation or exceeds the permitted use, you will need to obtain permission directly from the copyright holder. To view a copy of this licence, visit http://creativecommons.org/licenses/by/4.0/. 


\section{References}

Alekseev AN, Chunikhin SP (1991) Virus exchange between feeding ticks in the absence of viremia in a vertebrate host (distant transmission) (in Russian). Med Parazitol (Moscow) 2:50-54

Amirova NA, Pakizh VI, Chepeliuk MA, Suprun VG, Sergeeva NI (1989) Ixodid ticks of Pavlodar province and their participation in the circulation of tularemia infection (in Russian). Parazitologiya 23:267-274

Bakhtushkina AI (2019) Some data on distribution and localization of the ixodid tick Dermacentor reticulatus on marals of Altai Republic (in Russian). In: 7th international scientific and practical conference "actual problems of agriculture of mountain areas". Gorno-Altaisk, pp 235-238

Balakhonov SV, Nikitin AY, Andaev EI, Allenov AV, Borisenko EA, Gordeiko NS, Zvereva TV, Krasnoshchekov VN, Adelshin RV, Borisova TI, Verzhutckaya YA, Vershinin EA, Sidorova EA (2012) Ecological-parasitologic characteristic of the combined tick-borne infection foci on the territory of APEC summit holding in 2012 (in Russian). Siberian Med J 111(4):67-71

Balashov YS (1972) Bloodsucking ticks (Ixodoidea), vectors of disease to man and animals. Entomol Soc Am 8:161-376

Barandika JF, Hurtado A, García-Sanmartín J, Juste RA, Anda P, García-Pérez AL (2008) Prevalence of tick-borne zoonotic bacteria in questing adult ticks from Northern Spain. Vector Borne Zoon Dis $8: 829-835$

Barandika JF, Olmeda SA, Casado-Nistal MA, Hurtado A, Juste RA, Valcárcel F, Anda P, Garcá-Pérez AL (2011) Differences in questing tick species distribution between Atlantic and continental climate regions in Spain. J Med Entomol 48:13-19

Beljaeva NS (1975) On the ecology of Dermacentor silvarum OL. (in Russian). Parazitologiya 9:352-353

Belova OA, Brisker SA, Karan LS, Kolyasnikova NM, Topychkanova NG, Kuvshinova IN, Timofeev DI, Rukavishnikov MY, Grishaev MP, Karganova GG (2013) Problem of TBE virus prevalence evaluation in natural populations of Dermacentor ticks. In: Proceedings of XII international Jena symposium on tick-borne diseases, 21-23 March 2013. Weimar, Germany, p 41

Belova OA, Burenkova LA, Karan LS, Kolyasnikova NM, Topychkanova NG, Kuvshinova IN, Timofeev ID, Rukavishnikov MY, Grishaev MP, Karganova GG (2014) The tick-borne encephalitis virus detection efficiency in the ixodid ticks (Acari: Ixodidae) with ELISA and real-time PCR (in Russian). Voprosy Virusol 59(5):38-43

Belozerov NV (1982) Diapause and biological rhythms in ticks. In: Obenchain FD, Galun R (eds) Physiol ticks. Pergamon, Oxford, pp 469-500

Bogdanov AS, Makenov MT, Medyanikova LV, Shchouchinova LD, Yakimenko VV (2017) Variability of mitochondrial cytochrome oxidase first subunit gene (COI) fragments in several tick species of the marginatus group (Ixodidae, Amblyomminae, Dermacentor). Biol Bull 44:379-383

Bolotova TA, Kulakova NV, Khasnatinov MA, Verzhutskaya YA, Andaev EI, Belikov SI (2014) Analysis of nucleotide sequences and determination of phylogenetic relationships of ticks Dermacentor silvarum (in Russian). Izv Irkutsk Gos Univ 8:10-14

Cao WC, Zhan L, He J, Foley JE, De Vlas SJ, Wu XM, Yang H, Richardus JH, Habbema JD (2006) Natural Anaplasma phagocytophilum infection of ticks and rodents from a forest area of Jilin Province, China. Am J Trop Med Hyg 75:664-668

Cerný J, Buyannemekh B, Needham T, Gankhuyag G, Oyuntsetseg D (2019) Hard ticks and tick-borne pathogens in Mongolia - A review. Ticks Tick Borne Dis 10:101268

Chistyakova NS, Larina NP, Mamedov DM, Penkin VR (2018) Ixodidae in eastern Zabaikalye, their medical and veterinary role (in Russian). In: Proceedings VII international scientific and practical conference on climate, ecology, and agriculture of Eurasia, pp. 227-232

Chitimia-Dobler L, Lemhöfer G, Król N, Bestehorn M, Dobler G, Pfeffer M (2019) Repeated isolation of tick-borne encephalitis virus from adult Dermacentor reticulatus ticks in an endemic area in Germany. Parasit Vectors 12:90

Danchinova GA, Khasnatinov IA, Shulunov SS, Arbatskaya AV, Badueva LB, Suntsova IV, Tchaporgina AA, Bogomazova IL, Timoshenko AF (2007) Fauna and ecology of ixodid ticks in Pribaikalye (in Russian). Acta Biomed Sci 3:86-89

Danchuk GM, Khazova TG, Zvereva NG (2012) Ecological and parasitological characterization of natural foci infections in Minusinsks steppe zone Krasnoyarsk Region (in Russian). Epidemiol Vaccine Prev 2(63):42-47

Dautel H, Dippel C, Oehme R, Hartelt K, Schettler E (2006) Evidence for an increased geographical distribution of Dermacentor reticulatus in Germany and detection of Rickettsia sp. RpA4. Int J Med Microbiol 296(S1):149-156 
Dedkov VG, Markelov ML, Gridneva KA, Bekova MV, Gmyl AP, Kozlovskaya LI, Karganova GG, Romanova LI, Pogodina VV, Yakimenko VV, Shipulin GA (2014) Prevalence of Kemerovo virus in ixodid ticks from the Russian Federation. Ticks Tick Borne Dis 5:651-655

Didyk YM, Blaňárová L, Pogrebnyak S, Akimov I, Pet'ko B, Víchová B (2017) Emergence of tick-borne pathogens (Borrelia burgdorferi sensu lato, Anaplasma phagocytophilum, Rickettsia raoultii and Babesia microti) in the Kyiv urban parks, Ukraine. Ticks Tick Borne Dis 8:219-225

Doroshchenko EK, Lisak OV, Rar VA, Suntsova OV, Savinova YS, Kozlova IV (2019) Species and genetic diversity of representatives of the Anaplasmataceae family found in the sympatry zone of the Ixodes, Dermacentor and Haemaphysalis genera ticks (in Russian). Acta Biomed Sci 4(2):127-135

Dragomeretskaya AG, Romanova AP, Trotsenko OE, Mzhelskaya TV (2018) The dynamics of tick vector infection rates with ixodid tick borreliosis causative agents in Khabarovsk region during the epidemic season of 2017-2018 (in Russian). Russ J Infect Immun 8:544-545

Eichenberger RM, Deplazes P, Mathis A (2015) Ticks on dogs and cats: A pet owner-based survey in a rural town in Northeastern Switzerland. Ticks Tick Borne Dis 6:267-271

Estrada-Peña A, Farkas R, Jaenson TGT, Koenen F, Madder M, Pascucci I, Salman M, Tarrés-Call J, Jongejan F (2013) Association of environmental traits with the geographic ranges of ticks (Acari: Ixodidae) of medical and veterinary importance in the Western Palearctic. A digital data set. Exp Appl Acarol 59:351-366

Evstaf'ev IL (2001) Tick-borne encephalitis in the Crimea: Results of 20 year study (in Russian). Med Parazitol (Moscow) 2:53-57

Filippova NA (1997) Fauna of Russia and neighbouring countries. Ixodid ticks of the subfamily Amblyomminae (in Russian). Nauka Publ., St. Petersburg, Russia

Filippova NA, Apanaskevich M (2005) Some aspects of intraspecific variability of the closely related species of the Dermacentor marginatus complex (Acari: Ixodidae) as demonstration of microevolutionary process (in Russian). Parazitologiya 39:337-364

Filippova N, Stekolnikov A (2007) Materials on the preimaginal stages of the ticks collected from small mammals in Western and Northern Caucasus (Acari: Ixodidae). Parazitologiya 41:3-22

Földvári G, Rigó K, Lakos A (2013) Transmission of Rickettsia slovaca and Rickettsia raoultii by male Dermacentor marginatus and Dermacentor reticulatus ticks to humans. Diagn Microbiol Inf Dis 76:387-389

Friedhoff KT (1988) Transmission of babesia. In: Ristic M (ed) Babesiosis of domestic animals and man. CRC Press, Boca Raton, pp 23-52

Genchi M, Prati P, Vicari N, Manfredini A, Sacchi L, Clementi E, Bandi C, Epis S, Fabbi M (2015) Francisella tularensis: no evidence for transovarial transmission in the tularemia tick vectors Dermacentor reticulatus and Ixodes ricinus. PloS ONE 10:e0133593

Gordeiko NS (2015) Mammals as the providers of preimaginal stages of Ixodes ticks in the south of Primorsky Krai (in Russian). Dal'nevostočnyj žurnal Infekc Patol 27:48-52

Grímsson F, Grimm G, Potts A, Zetter R, Renner SS (2018) A Winteraceae pollen tetrad from the early Paleocene of Western Greenland, and the fossil record of Winteraceae in Laurasia and Gondwana. J Biogeogr 45:567-581

Gubeidullina AH, Boiko WA, Lyubarskaya OD (2009) Fauna and population of ixodid ticks in forests of Ulyanovskii region, within two observation periods (1966-1969 and 2007-2008) (in Russian). Uchenye Zapiski Kazanskogo Universiteta Seriya Estestvennye Nauki 151:181-191

Guo T, Che Z, Liu Y, Cao JZ, Geng HS, Sun JL, Wang Z, Li CC (2009) Surveillance of ectozoa on the body of rodent and hedgehog in Beijing ports (in Chinese). Chin J Vector Biol Control 20:27-29

Han R, Yang J, Niu Q, Liu Z, Chen Z, Kan W, Hu G, Liu G, Luo J, Yin H (2018) Molecular prevalence of spotted fever group rickettsiae in ticks from Qinghai Province, northwestern China. Infect Genet Evol 57:1-7

He X, Zhao J, Fu S, Yao L, Gao X, Liu Y, He Y, Liang G, Wang H (2018) Complete genomic characterization of three tick-borne encephalitis viruses detected along the China-North Korea border, 2011. Vector Borne Zoon Dis 18:554-559

Hightower JM (2012) Examining the distribution of Francisella tularensis, the causative agent of tularemia, in Ukraine using ecological niche modeling, Master thesis, University of Florida, p 87

Hightower G, Enkhtaivan B, Baigalmaa B, Enkhtogtoh B, Bolorchimeg B, Battur B, Tuvshintulga B, Undraa B, Battsetseg B (2012) Molecular detection of zoonotic Anaplasma in vector ticks in Mongolia. Institute of Veterinay Medicine, Ulaanbaatar, p 22

Hightower J, Kracalik IT, Vydayko N, Goodin D, Glass G, Blackburn JK (2014) Historical distribution and host-vector diversity of Francisella tularensis, the causative agent of tularemia, in Ukraine. Parasit Vectors 7:453 
Hodžić A, Fuehrer HP, Duscher GG (2017a) First molecular evidence of zoonotic bacteria in ticks in Bosnia and Herzegovina. Transbound Emerg Dis 64:1313-1316

Hodžić A, Zörer J, Duscher GG (2017b) Dermacentor reticulatus, a putative vector of Babesia cf. microti (syn. Theileria annae) piroplasm. Parasitol Res 116:1075-1077

Hofmeester TR, van der Lei PB, Docters van Leeuwen A, Sprong H, van Wieren SE (2016) New foci of Haemaphysalis punctata and Dermacentor reticulatus in the Netherlands. Ticks Tick Borne Dis 7:367-370

Hornok S, Farkas R (2009) Influence of biotope on the distribution and peak activity of questing ixodid ticks in Hungary. Med Vet Entomol 23:41-46

Hornok S, Meli ML, Gönczi E, Halász E, Takács N, Farkas R, Hofmann-Lehmann R (2014) Occurrence of ticks and prevalence of Anaplasma phagocytophilum and Borrelia burgdorferi s.1. in three types of urban biotopes: Forests, parks and cemeteries. Ticks Tick Borne Dis 5:785-789

Igolkina Y, Rar V, Vysochina N, Ivanov L, Tikunov A, Pukhovskaya N, Epikhina T, Golovljova I, Tikunova N (2018) Genetic variability of Rickettsia spp. in Dermacentor and Haemaphysalis ticks from the Russian Far East. Ticks Tick Borne Dis 9:1594-1603

Janjić P, Sarvan D, Tomanović S, Ćuk J, Krstić V, Radonjić V, Kovačević Filipović M, Ajtić J (2019) A short-term and long-term relationship between occurrence of acute canine babesiosis and meteorological parameters in Belgrade, Serbia. Ticks Tick Borne Dis 10:101273

Jia N, Zheng YC, Jiang JF, Jiang RR, Jiang BG, Wei R, Liu HB, Huo QB, Sun Y, Chu YL, Fan H, Chang QC, Yao NN, Zhang WH, Wang H, Guo DH, Fu X, Wang YW, Krause PJ, Song JL, Cao WC (2018) Human babesiosis caused by a Babesia crassa-like pathogen: a case series. Clin Inf Dis 67:1110-1119

Jiang JF, Jiang BG, Yu JH, Zhang WY, Gao HW, Zhan L, Sun Y, Zhang XA, Zhang PH, Liu W, Wu XM, Xu RM, Cao WC (2011) Anaplasma phagocytophilum infection in ticks, China-Russia border. Emerg Infect Dis 17:932-934

Jongejan F, Ringenier M, Putting M, Berger L, Burgers S, Kortekaas R, Lenssen J, van Roessel M, Wijnveld M, Madder M (2015) Novel foci of Dermacentor reticulatus ticks infected with Babesia canis and Babesia caballi in the Netherlands and in Belgium. Parasit Vectors 8:232

Jurišić A, Petrović A, Rajković D, Beuković M (2012) Monitoring of tick species (Acari: Ixodidae) in Vojvodina hunting resorts. In: International symposium on hunting: modern aspects of sustainable management of game population. Zemun-Belgrade, Serbia, pp 122-125

Kahl O, Dautel D (2013) Seasonal life cycle organisation of the ixodid tick Dermacentor reticulatus in Central Europe. Implications on its vector role and distribution. Med Kuzbass 12:84-87

Kahl O, Janetzki C, Gray JS, Stein J, Bauch RJ (1992) Tick infection rates with Borrelia: Ixodes ricinus versus Haemaphysalis concinna and Dermacentor reticulatus in two locations in eastern Germany. Med Vet Entomol 6:363-366

Kahl O, Gern L, Eisen L, Lane R (2002) Ecological research on Borrelia burgdorferi sensu lato: terminology and some methodological pitfalls. In: Gray J, Kahl O, Lane R, Stanek G (eds) Lyme borreliosis: biology, epidemiology and control. CABI Publishing, New York, pp 29-46

Karbowiak G, Biernat B, Werszko J, Rychlik L (2016) The transstadial persistence of tick-borne encephalitis virus in Dermacentor reticulatus ticks in natural conditions. Acta Parasitol 61:201-203

Khasnatinov MA, Liapunov AV, Manzarova EL, Petrova IV, Danchinova GA, Kulakova NV (2016) The diversity and prevalence of hard ticks attacking human hosts in Eastern Siberia (Russian Federation) with first description of invasion of non-endemic tick species. Parasitol Res 115:501-510

Kholodilov IS, Belova OA, Motuzova OV, Gmyl AP, Romanova LY, Boiko VA, Kryuchkov RA, Orlova O, Pakskina ND, Shamsutdinov AF, Karganova GG (2014) Ambiguous interpretation of the results of TBEV prevalence in ticks evaluation using different methods (in Russian). Epidemiol i vakcinoprofilaktika 76(3):29-36

Kholodilov I, Belova O, Burenkova L, Korotkov Y, Romanova L, Morozova L, Kudriavtsev V, Gmyl L, Belyaletdinova I, Chumakov A, Chumakova N, Dargyn O, Galatsevich N, Gmyl A, Mikhailov M, Oorzhak N, Polienko A, Saryglar A, Volok V, Yakovlev A, Karganova G (2019) Ixodid ticks and tick-borne encephalitis virus prevalence in the South Asian part of Russia (Republic of Tuva). Ticks Tick Borne Dis 10:959-969

Kiefer D, Pfister K, Tserennorov D, Bolormaa G, Otgonbaatar D (2010) Current state of Ixodidae research in Mongolia, Exploration into the biological resources of Mongolia. http://digitalcom mons.unl.edu/biolmongol/48

Kirillova NY, Kirillov AA (2018) Overview of ectoparasites of vertebrates in the Samara region (in Russian). Izv RAS SamSC 20(5-2):180-195

Kjaer LJ, Soleng A, Skarsfjord Edgar K, Lindstedt HEH, Paulsen KM, Andreassen AK, Korslund L, Kjelland V, Slettan A, Stuen S, Kjellander P, Christensson M, Teräväinen M, Baum A, Isbrand A, Jensen 
LM, Klitgaard K, Bødker R (2019) A large-scale screening for the taiga tick, Ixodes persulcatus, and the meadow tick, Dermacentor reticulatus, in southern Scandinavia, 2016. Parasit Vectors 12:338

Klitgaard K, Chriél M, Isbrand A, Jensen TK, Bødker R (2017) Identification of Dermacentor reticulatus ticks carrying Rickettsia raoultii on migrating jackal, Denmark. Emerg Inf Dis 23:2072-2074

Kohn M, Krücken J, McKay-Demeler J, Pachnicke S, Krieger K, von Samson-Himmelstjerna G (2019) Dermacentor reticulatus in Berlin/Brandenburg (Germany): activity patterns and associated pathogens. Ticks Tick Borne Dis 10:191-206

Kolonin GV, Baranov NI, Gorelikov VN (1984) New data on tick-borne encephalitis in the Maritime Territory (in Russian). Med Parazitol (Moscow) 5:67-70

Korshunova OS (1967) Ixodid ticks and Rickettsia sibirica (Dermacentroxenus sibiricus) (field and experimental studies) (in Russian). In: Petrishcheva PA (ed) Biological relationships between disease vectors and pathogens. Meditsina, Moscow, pp 86-103

Korzikov VA, Vasilieva OL, Rogulenko AV (2018) Distribution and abundance of ixodid ticks in the Galkinsky and the Berezichy forestries of the national park Ugra (in Russian). In: 9th international scientific and practical conference on "Priroda i istoriya Pougor'ya", pp 75-79

Kottek M, Grieser J, Beck C, Rudolf B, Rubel F (2006) World map of the Köppen-Geiger climate classification updated. Meteorol Z 15:259-263

Kozlova TV, Ignat'kova AS, Dorofeev EM, Popov VP, Orlov DS (2016) Dissemination, abundance rates and epizootiological significance of the tick Dermacentor reticulatus in the territory of the Tula region (in Russian). Problemy Osobo Opasnykh Infektsii 2016/4:20-24

Kožuch O, Nosek J (1971) Transmission of tick-borne encephalitis (TBE) virus by Dermacentor marginatus and D. reticulatus ticks. Acta Virol 15:334

Krasikov AP, Rudakov NV, Beisembaev KK, Samoilenko IE (2007) Experimental study of the role of ticks in transmission of bovine anaplasmosis (in Russian). Vet Patol 2(22):95-102

Krčmar S (2019) Diversity, ecology, and seasonality of hard ticks (Acari: Ixodidae) in eastern Croatia. J Vector Ecol 44:18-29

Krčmar S, Ferizbegović J, Lonić E, Kamberović J (2014) Hard tick infestation of dogs in the Tuzla area (Bosnia and Herzegovina). Vet Arhiv 84:177-182

Kruglyak SP, Leonova GN (1989) The importance of ixodid ticks in the south of the Far East in the circulation of the Powassan virus (in Russian). Voprosy Virusol 3:358-362

Kubiak K, Sielawa H, Dziekońska-Rynko J, Kubiak D, Rydzewska M, Dzika E (2018) Dermacentor reticulatus ticks (Acari: Ixodidae) distribution in north-eastern Poland: an endemic area of tickborne diseases. Exp Appl Acarol 75:289-298

Kudryavtseva TY, Popov VP, Mokrievich AN, Pakskina ND, Kholin AV, Mazepa AV, Kulikalova E, Trankvilevsky DV, Khramov MV (2018) Dyatlov IA (2018) Tularemia: Relevant issues and forecast of epidemic situation in the territory of the Russian Federation in 2018 (in Russian). Problemy Osobo Opasnykh Infektsii 1:22-29

Kulik I, Vinokurova N (1983a) Range of the tick Dermacentor silvarum in the USSR (in Russian). Med Parazitol 52:23-28

Kulik IL, Vinokurova NS (1983b) Distribution range of the meadow tick Dermacentor pictus (Ixodidae) in the USSR (in Russian). Parazitologiya 17:207-213

Kurganova OP, Perepelitsa AA, Makeeva LS, Burdinskaya EN (2015) Features of manifestation of natural foci of infections transmitted by ticks on the territory of Amur Oblast (in Russian). Dal'nevostočnyj žurnal Infekc Patol 26:33-35

Labuda M, Alves MJ, Eleočková E, Kožuch O, Filipe AR (1997) Transmission of tick-borne bunyaviruses by cofeeding ixodid ticks. Acta Virol 41:325-328

Leonova GN, Kondratov IGEVR, Ternovoi Protopopova EV, Chausov EV, Pavlenko EV, Ryabchikova EI, Belikov SI, Loktev VB (2009) Characterization of Powassan viruses from Far Eastern Russia. Arch Virol 154:811-820

Leonova GN, Bondarenko EI, Khvorostyanko AA, Kurlovskaya AV (2015) Study distribute pathogens of tick-borne infections, transmitted of ticks in the south of the Far East (in Russian). Epidemiol Vaccine Prev 1(80):31-35

Leonova GN, Lubova VA, Ivanis VA (2018) Monitoring causative agents of tick-borne infections in Primorsky Krai (2014-2018) (in Russian). Pac Med J 4(74):10-14

Leschnik MW, Khanakah G, Duscher G, Wille-Piazzai W, Hörweg C, Joachim A, Stanek G (2012) Species, developmental stage and infection with microbial pathogens of engorged ticks removed from dogs and questing ticks. Med Vet Entomol 26:440-446

Li J, Cao W, Zhang X, Xiaoming XW, Zhenying ZD, Zhao Q, Yang H (2002) Investigation on ticks and mice in forest areas of Beijing, China (in Chinese). Chin J Vector Biol Control 13:165-168 
Ličková M, Fumačová Havlíková S, Sláviková M, Slovák M, Drexler JF, Klempa B (2020) Dermacentor reticulatus is a vector of tick-borne encephalitis virus. Ticks Tick Borne Dis 11:101414

Liu H, Li Q, Zhang X, Li Z, Wang Z, Song M, Wei F, Wang S, Liu Q (2016) Characterization of rickettsiae in ticks in northeastern China. Parasit Vectors 9:498

Lubova VA, Leonova GN, Bondarenko EI (2017) Natural foci of tick-borne infections on the southeast areas of Sikhote-Alin complex characteristics (in Russian). Health Med Ecol Sci 1(68):30-35

Matushchenko AA, Rudakova SA, Korenberg EI (1993) Preliminary results of ecologic and epidemiologic studies of Lyme disease in West Siberia (in Russian). Med Parazitol (Moscow) 4:27-29

Mediannikov O, Matsumoto K, Samoylenko I, Drancourt M, Roux V, Rydkina E, Davoust B, Tarasevich I, Brouqui P, Fournier PE (2008) Rickettsia raoultii sp. nov., a spotted fever group rickettsia associated with Dermacentor ticks in Europe and Russia. Int J Syst Evol Microbiol 58:1635-1639

Medlock JM, Hansford KM, Vaux AGC, Cull B, Abdullah S, Pietzsch ME, Wall R, Johnson N, Phipps LP (2017) Distribution of the tick Dermacentor reticulatus in the United Kingdom. Med Vet Entomol 31:281-288

Meng F, Ding M, Tan Z, Zhao Z, Xu L, Wu J, He B, Tu C (2019) Virome analysis of tick-borne viruses in Heilongjiang province, China. Ticks Tick Borne Dis 10:412-420

Merino FJ, Nebreda T, Serrano JL, Fernández-Soto P, Encinas A, Pérez-Sánchez R (2005) Tick species and tick-borne infections identified in population from a rural area of Spain. Epidemiol Infect 133:943-949

Michelet L, Joncour G, Devillers E, Torina A, Vayssier-Taussat M, Bonnet SI, Moutailler S (2016) Tick species, tick-borne pathogens and symbionts in an insular environment off the coast of Western France. Ticks Tick Borne Dis 7:1109-1115

Milintsevich AV, Abramov AV, Kuvshinova PS (2016) The species composition of the ixodid ticks parasitizing dogs in the city of Yekaterinburg (in Russian). Molodezh' i Nauka 5(1):UDC 636.093

Movila A, Uspenskaia I, Toderas I, Melnic V, Conovalov J (2006) Prevalence of Borrelia burgdorferi sensu lato and Coxiella burnetii in ticks collected in different biocenoses in the Republic of Moldova. Int J Med Microbiol 296:172-176

Muñoz-Leal S, Venzal JM, Nava S, Reyes M, Martins TF, Leite RC, Vilela VLR, Benatti HR, Ríos-Rosas D, Barros-Battesti DM, González-Acuña D, Labruna MB (2018) The geographic distribution of Argas (Persicargas) miniatus and Argas (Persicargas) persicus (Acari: Argasidae) in America, with morphological and molecular diagnoses from Brazil, Chile and Cuba. Ticks Tick Borne Dis 9:44-56

Naumov RL, Gutova VP, Chunikhin SP (1980) Ixodid ticks and the causative agent of tick-borne encephalitis. 2. The genera Dermacentor and Haemaphysalis (in Russian). Med Parazitol (Mosk) 49:66-69

Niu Q, Liu Z, Yang J, Yu P, Pan Y, Zhai B, Luo J, Yin H (2016) Genetic diversity and molecular characterization of Babesia motasi-like in small ruminants and ixodid ticks from China. Infect Genet Evol 41:8-15

Norkina AS (2016) Ixodid ticks of the Orenburg Urals and some features of their ecology (in Russian). Izv Orenbg Gos Agrar Univ 57:163-164

Nosek J (1972) The ecology and public health importance of Dermacentor marginatus and D. reticulatus ticks in Central Europe. Folia Parasitol (Praha) 19:93-102

Obert AS, Kurepina NY, Bezrukov GV, Merkushev OA, Cherkashina EN, Kalinina UV (2015) Ixodid ticks as carriers of human transmissible infectious diseases in Altai Krai (in Russian). J Altai Branch Russ Geogr Soc 37:82-89

Olivieri E, Zanzani SA, Latrofa MS, Lia RP, Dantas-Torres F, Otranto D, Manfredi MT (2016) The southernmost foci of Dermacentor reticulatus in Italy and associated Babesia canis infection in dogs. Parasit Vectors 9:213

Olivieri E, Gazzonis AL, Zanzani SA, Veronesi F, Manfredi MT (2017) Seasonal dynamics of adult Dermacentor reticulatus in a peri-urban park in Southern Europe. Ticks Tick Borne Dis 8:772-779

Olsufiev N, Petrov VG (1967) Blood-sucking arthropods and Francisella tularensis (in Russian). In: Petrishcheva PA (ed) Biological relationships between disease vectors and pathogens. Meditsina, Moscow, pp 200-218

OpenStreetMap contributors (2017) Planet dump. https://planet.osm.org. https://www.openstreetmap.org

Paulauskas A, Radzijevskaja J, Mardosaitė-Busaitienė D, Aleksandravičienė A, Galdikas M, Krikštolaitis R (2015) New localities of Dermacentor reticulatus ticks in the Baltic countries. Ticks Tick Borne Dis 6:630-635

Pavlović I, Ivanović S, Dimitrić A, Vegara M, Vasić A, Živković S, Mijatović B (2016) Tick population in goats and sheep in Šabac. Mac Vet Rev 39:103-109

Pluta S (2011) Epidemiologie von Coxiella burnetii, Rickettsia spp., FSME- und Hantaviren in Süddeutschland unter Berücksichtigung klimatischer Veränderungen (in German), $\mathrm{PhD}$ thesis, University of Hohenheim, p 255 
Pluta S, Hartelt K, Oehme R, Mackenstedt U, Kimmig P (2010) Prevalence of Coxiella burnetii and Rickettsia spp. in ticks and rodents in Southern Germany. Ticks Tick Borne Dis 1:145-147

Pukhovskaya NM, Morozova OV, Vysochina NP, Belozerova NB, Bakhmetyeva SV, Zdanovskaya NI, Seligman SJ, Ivanov LI (2018) Tick-borne encephalitis virus in arthropod vectors in the Far East of Russia. Ticks Tick Borne Dis 9:824-833

Pukhovskaya NM, Morozova OV, Vysochina NP, Belozerova NB, Ivanov LI (2019) Prevalence of Borrelia burgdorferi sensu lato and Borrelia miyamotoi in ixodid ticks in the Far East of Russia. Int J Parasitol Parasit Wildl 8:192-202

R Development Core Team (2019) R: a language and environment for statistical computing, version 3.6.1. R Foundation for Statistical Computing, Vienna, Austria, ISBN 3-900051-07-0, http:// www.R-project.org

Radzijevskaja J, Paulauskas A, Aleksandraviciene A, Jonauskaite I, Stanko M, Karbowiak G, Petko B (2015) New records of spotted fever group rickettsiae in Baltic region. Microbes Infect 17:874-878

Raoult D, Lakos A, Fenollar F, Beytout J, Brouqui P, Fournier PE (2002) Spotless rickettsiosis caused by Rickettsia slovaca and associated with Dermacentor ticks. Clin Infect Dis 34:1331-1336

Rar V, Epikhina T, Suntsova O, Kozlova I, Lisak O, Pukhovskaya N, Vysochina N, Ivanov L, Tikunova N (2014) Genetic variability of Babesia parasites in Haemaphysalis spp. and Ixodes persulcatus ticks in the Baikal region and Far East of Russia. Infect Genet Evol 28:270-275

Rementsova MM, Khrushcheva NF (1967) Ixodid ticks and Brucella (in Russian). In: Petrishcheva PA (ed) Biological relationships between disease vectors and pathogens. Meditsina, Moscow, pp 219-232

Remesar S, Diaz Fernández P, Venzal JM, Pérez-Creo A, Prieto A, Estrada-Peña A, López CM, Panadero R, Fernández G, Diez-Baños P, Morrondo P (2019) Tick species diversity and population dynamics of Ixodes ricinus in Galicia (north-western Spain). Ticks Tick Borne Dis 10:132-137

René-Martellet M, Moro CV, Chêne J, Bourdoiseau G, Chabanne L, Mavingui P (2015) Update on epidemiology of canine babesiosis in Southern France. BMC Vet Res 11:223

Romanenko V, Sokolenko VV, Maximova YV (2017) Local formation of high population density of the ticks Dermacentor reticulatus (Parasitiformes, Ixodidae) in Tomsk. Entomol Rev 97:1391-1396

Rubel F, Kottek M (2010) Observed and projected climate shifts 1901-2100 depicted by world maps of the Köppen-Geiger climate classification. Meteorol Z 19:135-141

Rubel F, Brugger K, Monazahian M, Habedank B, Dautel H, Leverenz S, Kahl O (2014) The first German map of georeferenced ixodid tick locations. Parasit Vectors 7:477

Rubel F, Brugger K, Pfeffer M, Chitimia-Dobler L, Didyk YM, Leverenz S, Dautel H, Kahl O (2016) Geographical distribution of Dermacentor marginatus and Dermacentor reticulatus in Europe. Ticks Tick Borne Dis 7:224-233

Rubel F, Brugger K, Haslinger K, Auer I (2017) The climate of the European Alps: Shift of very high resolution Köppen-Geiger climate zones 1800-2100. Meteorol Z 26:115-125

Rubel F, Brugger K, Walter M, Vogelgesang JR, Didyk YM, Fu S, Kahl O (2018) Geographical distribution, climate adaptation and vector competence of the Eurasian hard tick Haemaphysalis concinna. Ticks Tick Borne Dis 9:1080-1089

Rudakova SA, Matuschenko EV, Yakimenko VV, Tokarevich NK, Andrejchuk YV (2005) A study of possible transovarial and transphase transmission of borreliae by the tick Dermacentor reticulatus (Ixodidae) (in Russian). Parazitologiya 39:427-432

Růžek D, Yakimenko VV, Karan LS, Tkachev SE (2010) Omsk haemorrhagic fever. Lancet 376:2104-2113

Rybár̆ová M, Honsová M, Papoušek I, Siroký P (2017) Variability of species of Babesia Starcovici, 1893 in three sympatric ticks (Ixodes ricinus, Dermacentor reticulatus and Haemaphysalis concinna) at the edge of Pannonia in the Czech Republic and Slovakia. Folia Parasitol 64:028

Samoilenko IE, Reshetnikova TA, Shalamova EV, Kumpan LV, Lebedeva MA, Tansev AK, Rudakov NV (2011) New foci of rickettsiosis in the Nazyaev district of Omsk region (in Russian). Natsional'nyye prioritety Rossii 2(5):141-142

Samoylenko IE, Shpynov SN, Yakimenko VV, Rudakov NV (2013) The study of adaptation of Rickettsia raoultii to major vectors - ticks of the genus Dermacentor using experimental methods (in Russian). Sibirskiy Meditsinskiy Zhurnal 120(5):59-61

Santos-Silva MM, Beati L, Santos AS, De Sousa R, Núncio MS, Melo P, Santos-Reis M, Fonseca C, Formosinho P, Vilela C, Bacellar F (2011) The hard-tick fauna of mainland Portugal (Acari: Ixodidae): an update on geographical distribution and known associations with hosts and pathogens. Exp Appl Acarol 55:85-121

Schreiber C, Krücken J, Beck S, Maaz D, Pachnicke S, Krieger K, Gross M, Kohn B, von SamsonHimmelstjerna G (2014) Pathogens in ticks collected from dogs in Berlin/Brandenburg, Germany. Parasit Vectors 7:535 
Seryodkin IV, Thomas L, Birtles R, Lewis J, Makenov MT, Petrunenko YK, Goodrich JM, Miquelle DG (2018) Tick-borne pathogens in Ixodidae ticks and their large mammalian hosts in the Russian Far East (in Russian). Parazitologiya 51:239-252

Shamsutdinov AF, Boyko VA, Trifonov VA, Fassakhov RS, Reshetnikova ID, Kryuchkov RA, Agafonova EV (2015) Analysis of the epidemiological situation in the natural focal zooanthroponoses in the regional infectious pathology in Tatarstan Republic (in Russian). Pract Med 7(92):120-123

Shchuchinova L, Kozlova I, Zlobin V (2015) Influence of altitude on tick-borne encephalitis infection risk in the natural foci of the Altai Republic, Southern Siberia. Ticks Tick Borne Dis 6:322-329

Shpynov SN, Arseneva IV, Granitov VM, Rudakov NV (2008) Tick-borne rickettsiosis in Altai region: Epidemiological aspects, molecular-biological verification (in Russian). Sibirskij Medicinskij Zurnal (Irkutsk) 82:43-46

Shulunov SS, Khasnatinov MA, Glushenkova TV, Danchinova GA, Adelshin RV, Belikov SI (2007) Detection of pathogens of mite rickettsiosis, anaplasmosis and ehrlichiosis in ixodid ticks (in Russian). Bulletin ESSC SB RAMS 53:243-244

Sun Y, Xu R (2003) Ability of Ixodes persulcatus, Haemaphysalis concinna and Dermacentor silvarum to acquire and transstadially transmit the Lyme disease spirochete Borrelia garinii. Exp Appl Acarol $31: 151-160$

Sun J, Lin J, Gong Z, Chang Y, Ye X, Gu S, Pang W, Wang C, Zheng X, Hou J, Ling F, Shi X, Jiang J, Chen Z, Lv H, Chai C (2015) Detection of spotted fever group Rickettsiae in ticks from Zhejiang Province, China. Exp Appl Acarol 65:403-411

Sun RX, Lai SJ, Yang Y, Li XL, Liu K, Yao HW, Zhou H, Li Y, Wang LP, Mu D, Yin WW, Fang LQ, Yu HJ, Cao WC (2017) Mapping the distribution of tick-borne encephalitis in mainland China. Ticks Tick Borne Dis 8:631-639

Tian ZC, Liu GY, Shen H, Xie JR, Luo J, Tian MY (2012) First report on the occurrence of Rickettsia slovaca and Rickettsia raoultii in Dermacentor silvarum in China. Parasit Vectors 5:19

Tohov Y, Lutsuk S, Dyachenko Y (2013) Phenology of the genus Dermacentor ticks in Central Caucasus (in Russian). Parazitologiya 47:437-447

Turebekov N, Abdiyeva K, Yegemberdiyeva R, Dmitrovsky A, Yeraliyeva L, Shapiyeva Z, Amirbekov A, Oradova A, Kachiyeva Z, Ziyadina L, Hoelscher M, Froeschl G, Dobler G, Zinner J, Frey S, Essbauer S (2019) Prevalence of Rickettsia species in ticks including identification of unknown species in two regions in Kazakhstan. Parasit Vectors 12:197

Ulyanova NI, Bessonova MA, Zakharova VV, Klenov KN, Sukhomlinova UI (1969) Ixodid ticks from the Leningrad region and their role as reservoirs of agents of some bacterial diseases of men and animals (in Russian). Parazitologiya 3:223-227

Valitskaya A, Katin AA, Bragina EA, Shuman VA (2016) Comparative study of the role of the ixodid ticks Ixodes persulcatus and Dermacentor reticulatus in the epidemiological process of tick-borne encephalitis in the western part of Western Siberia (in Russian). In: Proceedings of VIII international scientific conference on 'reading in memory of Professor I. I. Barabash-Nikiforov', 10 March 2016, Voronezh, Russia, pp 21-26

Varloud M, Liebenberg J, Fourie J (2018) Early Babesia canis transmission in dogs within $24 \mathrm{~h}$ and $8 \mathrm{~h}$ of infestation with infected pre-activated male Dermacentor reticulatus ticks. Parasit Vectors 11:41

Verkhozina MM, Kozlova IV, Doroshchenko EK, Lisak OV, Demina TB, Tkachev SE, Dzhioev PY, Suntsova OV, Savinova YS, Paramonov AI, Zlobin VI (2017) Characteristics of genetic and phenotypic properties of tick-borne encephalitis virus strains isolated from various source on the territory of Eastern Siberia. Acta Biomed Sci 2:76-82

Volkov SA, Bessolytsina EA (2015) Study of tick infection with anaplasmosis and ehrlichiosis in different districts of the Kirov region (in Russian). In: Russian annual scientific and practical conference "society, science, innovation" (NPK-2015), Kirov, pp 139-141

Walter M, Vogelgesang JR, Rubel F, Brugger B (2020) Tick-borne encephalitis virus and its European distribution in ticks and endothermic mammals. Microorganisms 8:1065

Wang T, Yang X, Jia Q, Dong N, Wang H, Hu Y, Yu Z, Liu J (2017) Cold tolerance and biochemical response of unfed Dermacentor silvarum ticks to low temperature. Ticks Tick Borne Dis 8:757-763

Wang M, Zhu D, Dai J, Zhong Z, Zhang Y, Wang J (2018) Tissue localization and variation of major symbionts in Haemaphysalis longicornis, Rhipicephalus haemaphysaloides, and Dermacentor silvarum in China. Appl Environ Microbiol 84:pii: e00029-18

Wei F, Song M, Liu H, Wang B, Wang S, Wang Z, Ma H, Li Z, Zeng Z, Qian J, Liu Q (2016) Molecular detection and characterization of zoonotic and veterinary pathogens in ticks from Northeastern China. Front Microbiol 7:1913 
Wen J, Jiao D, Wang JH, Yao DH, Liu ZX, Zhao G, Ju WD, Cheng C, Li YJ, Sun Y (2014) Rickettsia raoultii, the predominant Rickettsia found in Dermacentor silvarum ticks in China-Russia border areas. Exp Appl Acarol 63:579-585

Yamaguti N, Tipton VJ, Keegan HL, Toshioka S (1971) Ticks of Japan, Korea, and the Ryukyu Islands. Brigham Young University Science Bulletin, Biological Series, 15, 226 pp, Provo, Utah, USA

Yankovskaya YD, Shashina NI, Karan LS, Germant OM, Akimkin VG (2017) Epidemiological and parasitological aspects as well as special features of the prevention of infections transmitted by ixodid ticks in Moscow (in Russian). Epidemiol i vakcinoprofilaktika 93:80-85

Yu Z, Zheng H, Chen Z, Zheng B, Ma H, Liu J (2010) The life cycle and biological characteristics of Dermacentor silvarum Olenev (Acari: Ixodidae) under field conditions. Vet Parasitol 168:323-328

Yu Z, Zheng H, Yang X, Chen Z, Wang D, Hao M, Yang Y, Liu J (2011) Seasonal abundance and activity of the tick Dermacentor silvarum in Northern China. Med Vet Entomol 25:25-31

Zhang F, Liu W, Wu XM, Xin ZT, Zhao QM, Yang H, Cao WC (2008) Detection of Francisella tularensis in ticks and identification of their genotypes using multiple-locus variable-number tandem repeat analysis. BMC Microbiol 8:152

Zhang L, Li S, Huang SJ, Wang ZD, Wei F, Feng XM, Jiang DX, Liu Q (2018) Isolation and genomic characterization of lymphocytic choriomeningitis virus in ticks from northeastern China. Transbound Emerg Dis 65:1733-1739

Zhang G, Zheng D, Tian Y, Li S (2019) A dataset of distribution and diversity of ticks in China. Sci Data $6: 105$

Zhao S, Yang M, Jiang M, Yan B, Zhao S, Yuan W, Wang B, Hornok S, Wang Y (2019) Rickettsia raoultii and Rickettsia sibirica in ticks from the long-tailed ground squirrel near the China-Kazakhstan border. Exp Appl Acarol 77:425-433

Zhmaeva ZM, Pchelkina AA (1967a) Ixodid ticks and Rickettsia burnetii (in Russian). In: Petrishcheva PA (ed) Biological relationships between disease vectors and pathogens. Meditsina, Moscow, pp 59-85

Zhmaeva ZM, Pchelkina AA (1967b) Ixodid ticks and tick-borne encephalitis complex viruses (in Russian). In: Petrishcheva PA (ed) Biological relationships between disease vectors and pathogens. Meditsina, Moscow, pp 32-58

Zivkovic Z, Nijhof AM, de la Fuente J, Kocan KM, Jongejan F (2007) Experimental transmission of Anaplasma marginale by male Dermacentor reticulatus. BMC Vet Res 3:32

Zvereva TV, Allenov AV, Nikitin AY (2015) Species determined peculiarities of the tick-man contacts in the south of the Primorsky territory (in Russian). Problemy Osobo Opasnykh Infektsii 2015/4:14-17

Zygner W, Górsky P, Wedrychowicz H (2009) New localities of Dermacentor reticulatus tick (vector of Babesia canis canis) in Central and Eastern Poland. Pol J Vet Sci 12:549-555

Publisher's Note Springer Nature remains neutral with regard to jurisdictional claims in published maps and institutional affiliations.

\section{Affiliations}

\section{Franz Rubel ${ }^{1}$ (D) Katharina Brugger ${ }^{1}$ - Oxana A. Belova ${ }^{2}$. Ivan S. Kholodilov ${ }^{2}$. Yuliya M. Didyk ${ }^{3,4}$ - Lina Kurzrock ${ }^{5}$. Ana L. García-Pérez ${ }^{6}$. Olaf Kahl ${ }^{7}$}

1 Unit for Veterinary Public Health and Epidemiology, University of Veterinary Medicine Vienna, Veterinärplatz 1, 1210 Vienna, Austria

2 Chumakov Institute of Poliomyelitis and Viral Encephalitides, FSBSI "Chumakov FSC R\&D IBP RAS", Moscow, Russia

3 Institute of Zoology SAS, Bratislava, Slovakia

4 Schmalhausen Institute of Zoology NAS of Ukraine, Kiev, Ukraine

5 IDEXX GmbH, Ludwigsburg, Germany

6 NEIKER, Department of Animal Health, Vitoria-Gasteiz, Spain

7 tick-radar GmbH, Berlin, Germany 